ISSN Awaiting receipt (Print) ISSN Awaiting receipt (online)

\title{
ASIAN JOURNAL OF RESEARCH
}

№2 (2) 2017

http://www.journalofresearch.asia info@journalofresearch.asia

Japan, Osaka 


\section{Asian Journal of}

\section{Research}

№ 2 (2), March 2017

\section{Social Sciences and Humanities}

Japan, Osaka 
Founder and publisher Yoshiro Fujii

Asian Journal of Research is open access journal. Any part of journal may be reprinted or reproduced for academic and research purpose only.

Published since January 2017 year. Issued Monthly.

Editorial office: JAPAN, 6F Shin Osaka Dai 3 Doi Building, 1-8-24 Nishimiyahara

Yodogawa-ku, Osaka-shi, Osaka, 532-0004 Phone: +81 6-6264-9800

Internet address: http://www.journalofresearch.asia

E-mail: info@journalofresearch.asia

Circulation 200 copies. Free of charge.

Chief in Editor

\begin{tabular}{|l|l|l|l|}
\hline $\begin{array}{l}\text { Ph.D. Assistant professor at } \\
\text { Akdeniz University }\end{array}$ & Saeed Bagheri & Country: (Turkey) & Index \\
& & Area: (Social science and & Scopus \\
& humanities) & \\
& & Email: sbocanli@gmail.com & \\
& & $(90) 2422274400 / 4400$ & \\
00905348538165 & \\
\hline
\end{tabular}

\section{Editorial board}

\begin{tabular}{|c|c|c|}
\hline $\begin{array}{lll}\text { Ph.D. } & \text { Associate } & \text { professor } \\
\text { Xiamen } & \text { University } & \text { Tan Kah } \\
\text { Kee } & & \\
\end{array}$ & Jia Wei & $\begin{array}{l}\text { Area: (Social science and humanities) } \\
\text { Country: (China) } \\
\text { Email: weijia1988cupl@qq.com } \\
\text { +86 133-2111-3119 }\end{array}$ \\
\hline Manager of Shin Kobe clinic & Yoshiro Fujii & $\begin{array}{l}\text { Area: (Life Sciences) } \\
\text { Country: (Japan) } \\
\text { Email: info@journalofresearch.asia }\end{array}$ \\
\hline PhD, Associate professor & Zahoor Pir & $\begin{array}{l}\text { Area: (Life Sciences) } \\
\text { Country: (India) } \\
\text { Email:pirzahoor@gmail.com } \\
\text { +919797188161 }\end{array}$ \\
\hline PhD, Associate professor & George G. Tumanishvili & $\begin{array}{l}\text { Area: (Social science and humanities) } \\
\text { Country: (Georgia) } \\
\text { Email: georgetumanishvili@gmail.com } \\
+420773477056\end{array}$ \\
\hline PhD, Associate professor & Zaur Azimov & $\begin{array}{l}\text { Area: (Social science and humanities) } \\
\text { Country: (Azerbaijan) } \\
\text { Email: phd82@mail.ru } \\
\text { Phone: 055519-61-94 }\end{array}$ \\
\hline $\begin{array}{l}\text { Meijo University School of } \\
\text { Pharmacy }\end{array}$ & Toshiaki Nikai & $\begin{array}{l}\text { Area: (Physical, Chemical Science and } \\
\text { Engineering) } \\
\text { Country: (Japan) }\end{array}$ \\
\hline $\begin{array}{l}\text { Professor at the Samara State } \\
\text { Academy of Culture and Arts }\end{array}$ & Sergey Zagadkin & $\begin{array}{l}\text { Area: (Social science and humanities) } \\
\text { Country: (Russia Federation) } \\
\text { Email: zagadkin_pianist@rambler.ru }\end{array}$ \\
\hline $\begin{array}{ll}\text { Department } & \text { of } \\
\text { Otorhinoryngology, } & \\
\text { KhoneKaen University } & \end{array}$ & Patorn Piromchai & $\begin{array}{l}\text { Area: (Health Science) } \\
\text { Country: (Thailand) } \\
\text { Email: patorn@gmail.com }\end{array}$ \\
\hline Chulalongkorn University & Viroj Wiwanitkit & $\begin{array}{l}\text { Area: (Physical, Chemical Science and } \\
\text { Engineering) } \\
\text { Country: Bangkok, Thailand }\end{array}$ \\
\hline
\end{tabular}

$\odot$ Collective of authors

${ }^{\odot}$ Asian Journal of Research 
Contents

pp.

1. Safarov Djakhongir Ismoilovich

CODIFICATION OF ENVIRONMENTAL LEGISLATION:

EXPERIENCE OF FOREIGN COUNTRIES

2. Dmytro Butrsev

GEOPOLITICAL ASPECTS OF UKRAINIAN CRISIS

3. Bazarova Dildora Bahadirovna

42-54

SUBSTANCES AND MEANING OF THE CONCEPT OF

STATE PROTECTION OF PARTICIPANTS OF THE CRIMINAL PROCESS

4. Khodjaqulova Nargiza Khosiyatkulovna

ASKING QUESTIONS AND ELICITING

5. Shukhrat Mashrabovich Mirzaev

THE COORDINATION AS A WAY OF ORGANIZE OF LAW ENFORCEMENT ACTIVITY

6. Khodjaqulova Nargiza Khosiyatkulovna

LEARNING STYLES AND METHODS OF TEACHING 


\title{
Safarov Djakhongir Ismoilovich, PhD, associated professor,
}

Head of the Department of the Institute for Monitoring of Current Legislation under the President of the Republic of Uzbekistan, Tashkent city, Islam Karimov Street, 43 E-mail: si_jaxongir@mail.ru

\section{CODIFICATION OF ENVIRONMENTAL LEGISLATION: EXPERIENCE OF FOREIGN COUNTRIES}

\begin{abstract}
The article compares legal experience of foreign countries in the sphere of codification of environmental legislation. Specific features of Ecological Codes of foreign countries are determined. The provisions of Ecological Codes of such countries as France, Sweden, Kazakhstan, etc. are analyzed. It is proposed to codify the environmental legislation of the Republic of Uzbekistan taking into account the positive experience of foreign countries. The conclusion is made that it is possible to apply positive legislative experience of the studied states in the legislation of Uzbekistan.
\end{abstract}

Key words: systematization, codification, code, environmental legislation, comparative analysis, Ecological code.

At this stage of development of the legislation of the Republic of Uzbekistan, codification of environmental legislation is an urgent and rather sensitive issue. At present, several scientific researches are devoted to various aspects of the codification of environmental 
legislation in the legal literature1. As professor Sh.H.Fayziev "The current state of the legislative basis of the environmental policy of the Republic of Uzbekistan requires the adoption of a new consolidating master codified act of a complex nature. The codification of environmental legislation is a complex legislative process that is based on the political, legal, socio-economic prerequisites for interaction between society and nature and the scientific and practical justification for the development of a normative act of new content" 2 .

In recent years, scientists have justified the need for the adoption of the Ecological Code, which requires the study of positive experience of foreign countries that have already adopted such codes, and take advantage of the accumulated experience in the drafting of the Ecological Code of the Republic of Uzbekistan. Since the experience of legal regulation and systematization of legislation in the sphere of protection and use of natural resources of other states is one of the factors determining the conditions and limits of the codification of environmental legislation of Uzbekistan.

Interest in the experience of systematization, especially the codification of the legislation of other countries, which at first glance is

\footnotetext{
${ }^{1}$ Juraev Yu.A. Ecological legislation of the Republic of Uzbekistan. The concept, basic general regulatory norms and codification problems // Davlat va huquq. - 1996. - No. 11; Kholmuminov J.T. Ecology and the law. - Tashkent: Adolat, 2000; Usmonov M.B. Problems of ecological legislation // Hayot va qonun. - 2002. - №2; Nigmatov A. Ecological law schemes and concepts. - Tashkent, 1999; Neklessa G.G. Law as a source of environmental law // Davlat va huquq. - 2000. - No.3 and others.

2 Fayziev Sh.H. Theoretical problems of legal support of environmental policy of the Republic of Uzbekistan. Diss. ... Doct. Jurid. Sciences. - Tashkent, 2004. - 100 p.
} 
not directly related to the study of patterns of systematization of legislation in Uzbekistan, nevertheless seems to be fully justified, based on general ideas about trends in the development of legislation. First of all, analyzing the successful experience of other countries in regulating relations, which in our doctrine is most often called environmental, allows us to use the most suitable legal frameworks for our conditions, to master progressive legal ways of influencing various actors in their interaction with the environment, to adopt mechanisms for implementing the relevant legal norms. The study of the legislation of other countries, even with a negative assessment of the possibilities of its use in the legislative activities of the Republic of Uzbekistan, and avoids mistaken steps, inappropriate legal regulations, etc. ${ }^{3}$

Some European countries, such as France and Sweden, have already codified environmental legislation (environmental legislation), while in other countries, for example, Germany is implementing a project to bring together all federal environmental laws under the common name of "Ecological Code". For this purpose, several years ago, a commission was set up to draft this code ${ }^{4}$.

It is important that study of foreign experience is important condition, legally necessary for the improvement of legal bases. It is a question of the legislation of those states in relation to which the Republic of Uzbekistan, based on international treaties, supports the

\footnotetext{
3 Ignatyeva I.A. Experience in the codification of environmental legislation in the CIS member states // Ecologicheskoe pravo. - 2007. - №3. - P. 27-28.

4 Gertrude Lubbe-Wolf. The main characteristics of Germany's environmental law // Gosudarstvo i pravo. - 2000. - №1. - P. 90.
} 
Asian Journal of Research

№ 2 (2), March 2017 www.journalofresearch.asia

info@journalofresearch.asia

policy of special rapprochement and joint development in various spheres of political, economic and social life. So, at present, our country is implementing in its legislation the principle of convergence of its legislation with the legislation of other states members of the Commonwealth of Independent States (CIS). In this regard, in this article we will also study the experience of codification of environmental legislation in the CIS member states. As one of the common interests of the Commonwealth countries is the quality of the environment: the Agreement on the Establishment of the Commonwealth of Independent States, signed on December 8, 1991 in Minsk, refers to cooperation in the field of environmental protection, participation in the creation of a comprehensive international system of environmental security to the sphere joint activities of the parties to the Agreement, implemented on an equal basis through the common coordinating institutions of the Commonwealth. In science, the principle of coordinated development (convergence) of the environmental legislation of the CIS countries was proposed $^{5}$. This principle is realized and specified in the norms of a number of international treaties of the CIS. Thus, Bowels Charter of the CIS member states, signed on March 27, 1997 in Moscow, proclaims the intention of these countries to make efforts for a phased approximation and harmonization of legislation in the field of exploration, use and conservation of mineral resources. The Agreement on Cooperation in the Field of Conservation and Utilization of the Genetic Resources of Cultural Plants of the CIS Member States (Minsk, June 4, 1999)

5 Golichenkov A.K. Section 4 of the Concept for the Formation of New Environmental Legislation of the Republic of Kazakhstan. - M.-Alma-Ata, 1995. 
proclaims, as the main goals and objectives of the cooperation of these countries, the approximation of the legislation of the parties in order to facilitate the exchange of plant genetic resources between the parties ${ }^{6}$.

The study of the environmental legislation of the CIS member states, as well as the processes of its improvement, is significant not only for the aforementioned legal reasons, but also for the objectively important essential circumstances of its formation and development due to the fact that a) historically all the CIS member states were included in the a single legal system, b) by the time of the creation of the CIS, the legal regulation of environmental relations in these states was at the same level, since before the collapse of the USSR, the republican legislation of the basis (C) the CIS member states have territories adjacent to each other, and thus, in many respects similar and even common environmental problems (such as the problem of the Aral Sea). Obviously, in such conditions, the success of the legal solution to environmental problems depends, among other things, on the factor of harmonization of the legislation of Uzbekistan and neighboring countries, which, in turn, predetermines in many ways the content of this legislation.

In general, we should fully agree that "external factors that influence the formation of legislation" are "related to objective processes of globalization and the internationalization of environmental problems and the harmonization of legislation and national interests to take into account progressive approaches to the legislative regulation of

\footnotetext{
6 Ignatyeva I.A. Experience in the codification of environmental legislation in the CIS member states / / Ecologicheskoe pravo. - 2007. - №3. - P. 27-30.
} 
environmental relations applied in foreign countries"7. It is equally important to examine the directions of the systematization of foreign legislation, and in particular its codification. Based on the recognition of the impact on the environmental legislation of these processes and interests, it is possible to ascertain the corresponding dependency vectors and when systematizing this legislation. The success, the quality of the systematization of national environmental legislation in one aspect of its implementation are due to the use of foreign experience in the systematization of environmental legislation.

Of course, the study of the experience of other states in which the systematization of the relevant legislation is either completed or is being worked on has vital importance for the process of systematization of environmental legislation, ensuring its greatest fruitfulness in terms of improving the quality of this legislation. In a number of stateparticipants in the CIS, these works are being developed. The Ecological Code came into force in the Republic of Kazakhstan. In some countries, codification work is in the planning stage (Russia, Ukraine, Kyrgyz Republic). The Concept of the Draft Ecological Code was officially approved in the Republic of Belarus and adopted by the developers of the said act.

It should be noted that the current codification of environmental legislation in the CIS countries is characterized by similar conceptual solutions: a) practically without alternative, the result of the codification

\footnotetext{
7 Brinchuk M.M. Theoretical problems of formation of legislation on the environment // Gosudarstvo i pravo. - 1998. - №12. - P. 80.
} 
in these states is the Ecological Code 8 ; B) as a rule, in the justification for the creation of the Ecological Code, it is pointed out that there is a need for modernizing legislation in the sphere in question, improving the mechanisms for its implementation, bringing it into line with international acts; C) the codification concerns mainly the legislation on environmental protection.

Thus, for example, the Decision of the Council of Ministers of the Republic of Belarus of December 16, 2005, No. 1460 approved the Concept of the Draft Ecological Code of the Republic of Belarus ${ }^{9}$, in accordance with which the Ecological Code is subject to development in 2006-2007. The quality of the Concept of the Draft Ecological Code of Belarus is substantially improved by the fact that it provides an overview of scientific research, publications, legislation of foreign states that are related to the subject of legal regulation of the draft code.

In this Conception, unfortunately, there is a lack of discipline and ambiguity in the decision of the main principle issue - which legislation should be systematized in the Ecological Code. The subject of legal regulation of the draft code in the Concept is the public relations arising

8 Y.S.Shamshuchenko, while justifying the form of the act during the codification in Ukraine, draws attention to the circumstance that "it is the form of the code as a system-forming legal act that is now actively used by the Ukrainian legislator in the process of codification of the industry law". (Shemshuchenko Yu.S. To the issue of the Ecological code of Ukraine // Problems of improving the methodology of teaching environmental, legal and agrarian legal studies in Russian law schools: Materials of the All-Russian Scientific Methodological Review / Under the editorship of G.B.Bysgrova - M., 2006. - P. 101).

9 The text of the Concept of the Draft Environmental Code of the Republic of Belarus is available on the website of the National Legal Internet Portal of the Republic of Belarus: http://pravo.by/weonpa/text.asp?start= 1 \& RN = C20501460 
Asian Journal of Research

№ 2 (2), March 2017 www.journalofresearch.asia

info@journalofresearch.asia

in connection with the protection of the environment, individual natural complexes and objects or components of their natural environment; the main goal is the codification of legislative acts in the field of environmental protection in the form of codification.

The authors of the Concept objectively cite critical remarks on the selected conceptual direction of codification: "The National Academy of Sciences of Belarus believed that the Code should regulate not only relations in the field of environmental protection, but also legal relations in the field of rational use of natural resources. Without laying ecological limits in the process of nature management, it is impossible to ensure sustainable use and conservation of resources. The division of the protection of natural resources and their use deprives the nature protection activity of the instruments that ensure its implementation". It is a pity that the justification for rejecting this approach in the Concept is too unconvincing. In particular, it is argued that "in the case of adopting the position of" broad codification, "there will be difficulties in harmonizing and unifying environmental norms and norms that regulate the use of certain types of natural resources (lands, bowels, waters, forests, fauna and flora, etc.)". But the fact is that the legislator himself set the task of such unification by the formation of the legislation on environmental protection, since the requirements established with regard to the environment as a whole inevitably affect the definition of the order of use and protection of its individual components. In other words, the necessary agreement is either already present in the legislation of the Republic of Belarus, or the above statement denies the 
Asian Journal of Research

№ 2 (2), March 2017 www.journalofresearch.asia

info@journalofresearch.asia

systemic nature of all Belarusian legislation, the interrelations and the mutual influence of its various branches.

In other words, when holding codification, four legislative acts will be merged into one act, forming this legislation. These are the Laws of the Republic of Belarus "On Environmental Protection", "On Waste", "On State Ecological Expertise", “On Specially Protected Natural Territories". On their basis, as well as on the basis of environmental regulations, 8 legislative acts of the natural resource sectors of legislation, it is proposed to create an Ecological Code, consisting of 124 articles grouped into 21 chapters.

It is planned to give in the Code the definition of necessary legal concepts, to determine the scope of application of legislation on environmental protection, the place of the Ecological Code in the system of legislation of the Republic of Belarus, and outline the basic principles of environmental protection. In general, the provisions of the Ecological Code will be set out in accordance with the structure adopted at the current time in the existing environmental laws.

Improvement of legislation on environmental protection is related at the same time with the planning of a number of chapters: chapters, the norms of which will concern the provision of information and dissemination of environmental information; the chapter "Nature management", where "general requirements for nature management (general and special) will be established", "legal bases for nature management" are determined. A chapter on regulation of relations in the sphere of waste management will be created. 
Asian Journal of Research

№ 2 (2), March 2017 www.journalofresearch.asia

info@journalofresearch.asia

Similar approaches are indicated in the scientific literature for Ukrainian codification. The task of developing the draft Ecological Code of Ukraine was set for a long time: it is envisaged by the main directions of the state policy of Ukraine in the field of environmental protection, use of natural resources and ensuring environmental safety, approved by the Rada (parliament) of Ukraine resolution of 5 March $1998^{10}$.

Proceeding from the alleged content of the Ecological Code, set forth by Yu.S.Shamshuchenko, his project will be repeated by the Law "On Environmental Protection", but, of course, with the elimination of the bill of law regulation, the general update of the legislation on environmental protection ${ }^{11}$. Currently, practical work on the creation of this act is related to the generalization of legislation on environmental protection. The prospects for taking it at the moment are very vague ${ }^{12}$.

From this perspective, the process is of particular importance to develop the project of the Ecological Code of the Russian Federation. Since the prospect of applying the deepest form of ordering and development of legislation - codification in the form of the Ecological Code of the Russian Federation - is now proposed in some programmatic documents and in journalism without serious consideration of the

\footnotetext{
10 Shemshuchenko Yu.S. To the issue of the Ecological code of Ukraine // Problems of improving the methodology of teaching environmental, legal and agrarian-law educational disciplines in law schools in Russia: materials of the All-Russian Scientific and Methodological Workshop / Ed. G.B.Bysgrova. - M., 2006. - P. 101.

11 At the same place. 104-105.

12 Shemshuchenko Yu.S. National Interests and Environmental Law // Jurnal rossiyskogo prava. - 2005. - № 12. - P. 93-94.
}

Social Sciences and Humanities

14 Generalization of Scientific Results 
matter ${ }^{13}$. At the present time, the Russian Federation has developed the concept of a draft federal law "The Ecological Code of the Russian Federation". And it says that the main idea of the bill is to improve the legal basis for state regulation of environmental protection and ensure environmental safety in modern socio-economic conditions and legal support for the implementation in the norms of the Ecological Code of the Russian Federation of the constitutional right of citizens to a favorable environment. The main objective of the development of the Ecological Code is to move from object-based to complex legal regulation of environmental relations, eliminate internal contradictions, fill gaps, harmonize environmental legislation with civil, administrative, environmental and other legislation, harmonize with international environmental law, establish new ones legal institutions that meet the modern requirements of economic development of society as much as possible the norms of direct action.

And also in the bill the subject of legal regulation of the Code is allocated. Such are public relations: on the protection of the environment, its individual components (natural objects) from the negative impact of economic and other activities; on the use of materials, products, production and other objects representing environmental hazards; on the management of production and consumption wastes; related to the establishment and definition of the regime of territories with a special environmental status associated with the implementation of the rights of citizens and public associations to access environmental

${ }^{13}$ Ignatyeva I.A. Ecological legislation of Russia: theory and practice of systematization. Author's abstract. Diss. ... Doct. Jurid. Sciences. - M., 2007. - P. 4. 
information, participate in the adoption of government decisions, access to justice in environmental matters. As can be seen from this position in the draft laws was an attempt to encompass both the relationship on nature protection and nature management, which we will not be able to see in the concepts and laws of other states.

From the point of view of systematization of environmental legislation, the Republic of Kazakhstan takes a special place, since it is the first among the CIS states to adopt the Ecological Code. In the Republic of Kazakhstan, work on the creation of the Ecological Code of the Republic of Kazakhstan from January 9, 2007, Law No. 212-111 began in 2004, when a special interdepartmental working group was established. Working group prepared the concept of reforming environmental legislation and the basic draft code. At the same time, "about 20 recommendatory and guiding documents of various international organizations, 14 international conventions, about 30 directives and laws of other states were mobilized"14.

The Ecological Code of the Republic of Kazakhstan ${ }^{15}$ consists of 9 sections, 47 chapters, 326 articles. He incorporated the Laws "On Environmental Protection", “On Environmental Expertise”, “On the Protection of Atmospheric Air". A special sequence in the selection of acts for codification is not observed. In particular, the Law “On Specially Protected Natural Territories" continues to operate, the norms of which

${ }^{14}$ IA “Kazinform”. March 14, 2006 // www.inform.kz.

15 Official website of the Ministry of Environmental Protection of the Republic of Kazakhstan // http://www.nature.kz/en/strategy/ecologycode/. 
Asian Journal of Research

№ 2 (2), March 2017 www.journalofresearch.asia

info@journalofresearch.asia

have not been codified in the Ecological Code of the Republic of Kazakhstan (EC RK).

In art.1 EC RK a list of 69 legal concepts and their definitions is given (without their arrangement in alphabetical order, which, undoubtedly, will practically complicate the use of such a long list). The concept of environmental legislation, used directly in the text of the EC $\mathrm{RK}$, is disclosed in art.2: it is based on its broad understanding of the range of acts included in it - as a set of normative legal acts. The principle of priority use of the EC RK in relation to other laws regulating relations in the field of environmental protection is reinforced. EC RK, as stated in art.3, regulates "relations in the field of protection, restoration and preservation of the environment, use and reproduction of natural resources in the conduct of economic and other activities related to the use of natural resources and environmental impact within the territory of the Republic of Kazakhstan". In reality, the relations regulated by it can not be characterized by such a wide scope. As follows from art.2.8 EC RK, a significant part of the laws of the environmental legislation system has not been absorbed by this act: "relations in the field of protection and use of environmental objects and specially protected natural areas are regulated by special laws of the Republic of Kazakhstan in the part not regulated by this Code".

As I.A.Ignatieva argues, "it is interesting to state a lengthy list of measures that constitute, in one case, state regulation (in relation to the protection of the environment), and in another, state control (as applied

to the use of natural resources). The bases for the use of various concepts (regulation, management) are not applicable to certain environmental 
Asian Journal of Research

№ 2 (2), March 2017 www.journalofresearch.asia

info@journalofresearch.asia

relations - environmental protection and nature management, especially since a number of functions are identical (control, monitoring)"16.

And also, "in the Ecological Code adopted erroneous, is the permit for the import of hazardous waste into the territory of Kazakhstan for the purpose of their use, utilization, processing, recycling, since in Ch. 42, art. 295, item 3 prohibits the export of hazardous wastes to the States Parties to the Basel Convention on the Control of Transboundary Movements of Hazardous Wastes and their Disposal and to developing countries that, under their legislation, have banned the import of hazardous wastes, or have reason to believe that the use of these wastes is not will be carried out in an environmentally sound manner"17.

Despite some minor shortcomings of the Ecological Code of the Republic of Kazakhstan, it is the first code of its kind in Central Asia and this, in our opinion, is a fairly successful move in the development of environmental legislation.

Among the novellas of the legislation on the protection of the environment it is necessary to name some norms of the most general content relating to environmental management activities. Article 10 defines the use of natural resources as "the use of natural resources and (or) environmental impact in the daily life of a person, in the economic and other activities of individuals and legal entities", generalizes the types of nature use, dividing it into general and special (grounds and the conditions for the emergence of the latter are discussed in Article 12 of

\footnotetext{
16 Ignatyeva I.A. Experience in the codification of environmental legislation in the CIS member states / / Ecologicheskoe pravo. - 2007. - №3. - P. 30.
}

17 Website: www.institutiones.com/general/190-2008-06-17-09-45-09.html 
the EC RK) and by the types of natural resources used (land use, water use, etc.). In art.11 summarizes the provisions on nature users. In part 1 of art.18 lists all state bodies in the field of the use of natural resources, designated in general terms in dependence on their competence. In Ch. 12 introduced a single concept of state control in the field of environmental protection, protection of reproduction and use of natural resources. Types of control are distinguished along with environmental control, depending on the types of natural resources. In Ch. 16 general rules of monitoring natural resources are being carried out. Chapter 18 defines uniform requirements for the management of natural resource cadastres. According to Art.149 in the Republic of Kazakhstan, a unified system of state cadastres of natural resources is being created and maintained. The Republic of Kazakhstan is an inter-sectoral information system that unites all types of state cadastres of natural resources of the Republic of Kazakhstan in order to provide a single state-wide integrated inventory and assessment of natural and economic of the Republic of Kazakhstan.

With the adoption of the EC RK, the structure of environmental standards is changing, which are now divided into environmental quality standards, emission standards and standards for the use and protection of natural resources. Emissions regulations are new concept in the environmental legislation of the Republic of Kazakhstan. EC RK referred to them technical specific emission standards, standards for maximum permissible emissions and discharges of polluting substances, standards for the location of production and consumption wastes, standards for permissible physical impacts (heat quantity, noise level, 
Asian Journal of Research

№ 2 (2), March 2017 www.journalofresearch.asia

info@journalofresearch.asia

vibration, ionizing radiation and other physical effects). Of these, technical specific emission standards are established in technical regulations for specific processes and industries based on the introduction of the best available technologies. These standards are the basis of integrated environmental permits. The latter, along with solutions for emissions into the environment, form a system of environmental permits, established in Ch. 8 EC RK.

EC RK stimulates nature users to implement international standards for environmental management system by quite accessible measures: dissemination of information on international standards, reduction of the frequency of inspections by environmental inspectors for nature users who have implemented international standards for the system of management of environmental protection and having a document confirming such implementation, use of mechanisms of economic regulation about environment.

In EC RK, the requirements for the conduct of environmental expertise, which is divided into state and public, are considered. EC RK preserves a long list of objects of state eco-environmental expertise, which include drafts of regulatory legal acts. With reference to the general ecological expertise, the EC RK has removed a lot of questions of procedural and technical character.

Chapter 9 provides for the procedure for conducting an environmental audit, which is divided into mandatory and proactive. Obligatory ecological audit should be carried out in the following cases: significant damage to the surrounding environment caused by economic and other activities of individuals and legal entities, documented in 
documentary evidence; reorganization of a legal entity - a nature user, carrying out ecologically dangerous types of economic and other activities, in the form of merger, division and separation; banks of legal entities - nature users, carrying out ecologically dangerous types of economic and other activities. In the EC RK, these are the ways of conducting an environmental audit, specific actions and their components are described.

The economic regulation of environmental protection (Section 3) contains a special element that has no analogues in the Uzbek legislation: market mechanisms and emissions quotas trading in the environment. The payment for emissions into the environment, as another independent element of economic regulation, is established, as defined in Art. 101 EC RK, the tax legislation. We believe that in this way a lot of questions are removed regarding the legality of collecting payments for negative impact on the environment. At the same time, there is no uniqueness in the solution of payment issues: thus, according to Art. 103 EC RK for the purpose of economic stimulation of effective implementation of environmental protection measures by nature users. The Government of the Republic of Kazakhstan may approve the marginal rates for emission charges to the environment.

Thus, EC RK, in spite of the general incompleteness of codification, still largely updated environmental legislation. EC RK laid the foundation for a legal understanding of environmental legislation in a broad sense in the aspect of regulated public relations; he demonstrates an attempt to generalize all the most general provisions relating to environmental management activities. In addition, the EC RK has 
Asian Journal of Research

№ 2 (2), March 2017 www.journalofresearch.asia

info@journalofresearch.asia

brought the Kazakh legislation into greater conformity with the European and international approach to regulating relevant attitudes: changed terminology, introduced a number of new legal concepts and modern legal institutions ${ }^{18}$.

We believe that the study of the experience of foreign countries, in particular CIS member states, with the supreme organization of lawmaking work, with due regard to systematization, can positively affect the quality of the updated environmental legislation of Uzbekistan. In a certain aspect, such studies are necessary, since they contribute to the improvement of mutual understanding of states at the contacts of Uzbekistan at the international level, including on environmental issues.

Study of the legislation of other countries also shows some inadequacy of the justifications for the decisions made and the approaches to the development of environmental legislation in other CIS countries. And these circumstances objectively limit the use of foreign experience, do not allow in some cases to make direct borrowings of legal institutions and individual norms. However, in this case, the experience of the CIS member states is of special value for the development of a scientific concept of the creation of the Ecological Code in the Republic of Uzbekistan, and the choice of a practical direction for the systematization of national environmental legislation.

In conclusion, we note that the practice of codification ecological legislation in other countries, of course, is essential to the development of Uzbek ecological legislation and systematizing it, including, but the use

18 Ignatyeva I.A. Experience in the codification of environmental legislation in the CIS member states / / Ecologicheskoe pravo. - 2007. - №3. - P. 33. 
Asian Journal of Research

№ 2 (2), March 2017 www.journalofresearch.asia

info@journalofresearch.asia

of its results for the purposes of the codification of national legislation must be weighted and conditioned as a general rule, the search for new mechanisms for the implementation of environmental legislation or similarity of legal approaches to the solution of certain problems in the legal regulation of environmental relations. 
Asian Journal of Research

№ 2 (2), March 2017 www.journalofresearch.asia

info@journalofresearch.asia

\section{Author information}

\section{Safarov Djakhongir Ismoilovich}

Since 2015: Independent researcher of the Tashkent State Law

University,

Since 2016: Head of the Department of the Institute for Monitoring of

Current Legislation under the President of the Republic of Uzbekistan

Date of birth: 09/02/1987

Birthplace: Bukhara region, Bukhara city

Nationality: Uzbek

Education: The highest

I have ended 2006 Tashkent State Law Institute

Specialty by training: lawyer

Academic degree: Candidate of juridical sciences (PhD)

Academic status: Associate professor

Interests - ecological law, agrarian law, land law, civil law, constitutional law.

Theme of research: "The system of legal acts in the sphere of ecology, and legal problems of their codification"

Summary of publications: 155 scientific works: 21 textbook and manuals, 134 articles.

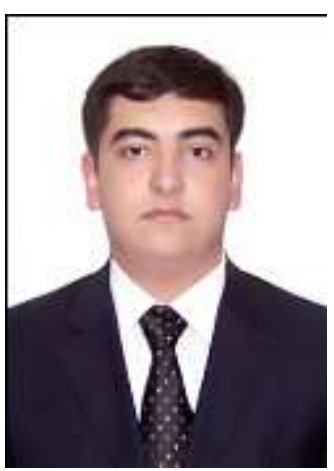




\section{GEOPOLITICAL ASPECTS OF UKRAINIAN CRISIS}

\section{Dmytro Butrsev,}

\section{PHD Candidate, Central China Normal University}

Understanding of real reasons of international conflicts remains to be a specifically difficult process and results of analysis sometimes can be unpredictable. However, the nature of each conflict depends on interests of each international actor or intentions of other international actors. During the Cold War, the difference between Socialistic and Democratic political forces on the international arena was clear. However, the majority of conflicts, which took place during the Cold War, had a clear ideological background, because of confrontation of two international superpowers, the United States of America and the Soviet Union. These superstates never fought face to face, because a direct military confrontation might cause a nuclear war. However, both of them used every chance to weaken an opponent or at least to prevent an opponent's influence spreading in a specific region. For example, that happened in Vietnam, Cuba, Afghanistan and other different countries of Middle East.

In order to expend spheres of influence, USSR and USA used all kinds of means: political, ideological, economic and military, supported allies and tried to force out opponent, created military and political alliances. Both camps had almost unlimited capabilities and created their own strategies for opposing the opponent. Both of international poles worked out their own mutual-deterrence strategies. The methods of different poles of international supercountries were also different, but 
final aim remained the same - own expansion and weakening of opponent. However, after collapse of Soviet Union the US became the only pole of real international power and took the role of "international policeman" for almost 15 years, a whole era. At the same Russian Federation inherited two opposite factors: a very weak economic system from the one side, and still having the imperial ambitions and designs from the other side. Nevertheless, it had not enough strength to fulfill this plan in reality during first 15 years of existence.

However, the main task of this paper is to show another side of relations between Russian Federation and United States of America, and a real conflict of interests since the end of Cold War and Ukrainian crisis of 2013-2015, as one of the remarkable moments during changes on the international geopolitical map, which has not stopped yet. This crisis brightly shows active continuation of attempts of the US to stay the only superpower, ignoring general rules of international society and their own democratic values and supporting the policy of double standards.

\section{American Geopolitical Ambitions after the end of the Cold War:} Theoretical assumptions and practical actions

After the collapse of the Soviet Union, USA remained to be the only international actor with powerful international influence. It is not surprising, that US obtained the role of "international policeman" having almost unlimited strangleholds in all spheres of international life. Nevertheless, according to chaotic nature of international relations, the complete domination cannot last forever, and American politicians 
understood this fact. In order not to lose the leadership as long as it was possible US claimed itself an informal international leader.

However, it is very important to notice some specific points of view of different political and geopolitical scientists, especially such outstanding personalities as Zbigniew Brzezinski and Samuel Phillips Huntington. Their geopolitical ideas about international relations during the last decade of $20^{\text {th }}$ and beginning of $21^{\text {st }}$ century influenced the whole scope of American foreign policy.

However, returning back to the Ukrainian topic and geopolitical theories, which have relation to this country, first of all is important to mention Zbigniew Brzezinski's book which is called "The Grand Chessboard: American Primacy and Its Geostrategic Imperatives". For the first, the book shows some important key ideas of American vision of international relations:

- $\quad$ Despite being separated from the Old Europe, US remained to be the only world leader after the End of the Cold War, and interested in the territories which were not under their control, so called heartland, which consists of central and eastern Eurasia territories (most of territories belong to Russian Federation and Ukraine)

- One of the most important details is that Russia, being economically, politically and socially weak, remained to be an uncontrollable for USA, even after the Soviet Union collapse.

- In this context, Ukraine, as a new geopolitical unit, became the central and the most important part of the American foreign policy. Furthermore, Ukraine was chosen not only as a final aim of American domination in Europe, but also as a tool of influence on a more powerful 
territory - Russia. The second one: from Brzezinski point of view, Russia will not be able become a new empire, and will not be complete without Ukraine. Therefore, US should use Ukraine as one of the transmitters of "traditional democratic values" from West to Russia in order to influence on a huge territory and to control the whole heartland.

- There is one more significant detail, which makes Ukraine considerable - its geographical location. Ukraine is situated in the real heart of Eurasian continent. It is a crossroad from East to West, from South to North. And also has an access to the Black Sea, which is very important for all actors in the region, even those who are remote. However, Ukraine has no any abilities to control the central part of Eurasian continent, and actually so-called heartland.

Thus Zbigniew Brzezinski outlined the strategic imperatives of the USA foreign policy in the post-bipolar period in a specific region.

Another American political and social scientist Samuel Huntington in his work "The Clash of Civilizations and the Remaking of World Order" underlines the importance of Ukraine as a country, which is crucially close to the "core" country of East European civilization Russia. In his masterpiece, he also underlines the importance of Ukraine for Russia as a part of civilization in which Russia is a "core". Nevertheless, being the second important country in the region after Russia, Ukraine is a cleft country. According to Huntington's idea this divide comes from the religious factor. However I would also notice that religion is just a part of cultural aspect. It is also important to underline that difference is a self-identification of Ukrainians as a separate nation, which belongs to another cultural group within or beyond the national 
Asian Journal of Research

№ 2 (2), March 2017 www.journalofresearch.asia

info@journalofresearch.asia

borders of the country, after becoming Ukraine a national state. This fact is also very important, because some parts of the country were connected to Ukrainian Soviet Socialist Republic till 1991 (for example Western regions were connected right after the Second World War, and Crimea in 1956). Ukraine also has a deep historical connection and history of interaction with many countries, for example, Poland, Hungary, Russia and Turkey. Also in this book Huntington allows the possibility of conflict within Ukrainian borders or conflict with Russia.

In that way, it is possible to make the following concussions:

1. Specific geographic location on international crossroads and broad seacoast give Ukraine advantageous geographical location and wide range possibilities for active and fast growth and gaining geopolitical and economic benefits.

2. However, from the other side this kind of location made Ukraine a "crossroad of wars" (beginning from 9th century and till the end $20^{\text {th }}$ century (from invasion of the Golden Horde to Hitler's invasion to USSR in 1941). Ukrainian territory was one of the biggest battlefields in a history, because all armies which were moving from west to east and from east to west crossed it in both directions. This fact made stable and steady independent national development almost impossible.

3. According to the following statements, the population of Ukraine is culturally (language, religion and other facts) and nationally diverse. At the same time the geographical and geopolitical location makes Ukraine specifically attractive for big international actors as a target for extending of their own sphere of influence, what, in specific 
conditions, makes a very high potential for inner conflicts. One of them happened at the end of 2013.

So, what about influence of the USA and its interest in the Ukrainian region and what were their actions?

After the collapse of Soviet Union Ukraine became one of the biggest holders of conventional and nuclear arm in Europe. This question was one of the most important for US during the first years of Ukrainian independence. At that time, Ukraine had no capabilities to secure the nuclear weapons, which were gained after the Soviet Union collapse. US financed full destruction of military facilities for possible exploitation of any nuclear weapon; the amount of financial aid was around 175 million dollars and 155 million dollars as a financial aid. American government foresaw Ukraine as an instrument of political pressure on Russia. One of the interesting documents of that time is also one of the resolutions of Congress of the USA. The most interesting resolution has number 120 and can be easily find on the website of the Congress. The resolution underlines the importance of Ukraine for the USA within American foreign policy in Europe. However, some statements within the declaration seem to be critical for understanding the real intentions and motives of the USA towards Ukraine. It is important to give some quotations for better understanding of this fact:

"Whereas Ukraine is a major European nation, having the second largest territory and sixth largest population of all the States of Europe; whereas Ukraine has an important geopolitical and economic role to play within Central and Eastern Europe and a strong, stable, and secure 
Asian Journal of Research

№ 2 (2), March 2017 www.journalofresearch.asia

info@journalofresearch.asia

Ukraine serves the interests of peace and stability in all of Europe, which is also an important national security interest of the United States".

According to this text, the USA in an open and frank manner declares a real importance of Ukraine for US. Also earlier in this article, I was writing about geopolitical view of Zbigniew Brzezinski, who worked in the Administration of the President of the USA. His words might be a kind of his personal opinion without any serious evidences; however, this quotation is a part of real high-level document, which confirms the opinion of Zbigniew Brzezinski. In fact, I think, Brzezinski himself was an author of this declaration, or at least took part in creation of this document.

1. The second quotation: "(11) the Government of Ukraine should continue to act in defense of its sovereignty and that of the other independent states of the former Soviet Union by opposing the emergence of any political or military organization which would have the potential to promote the reintegration of the states of the former Soviet Union".

Speaking about this quotation, first of all is important to underline the fact, that this paragraph directly puts Ukraine on the frontier of American anti-Russian ideology of US. As far as Russia was an international actor, which tried to rearrange the countries of former Soviet Union within a new international organization, Commonwealth of Independent States, USA saw a real threat of the Russian domination in the region through this organization.

There were a lot of other facts and attempts, which have been used during American spreading of influence in the Middle and Eastern 
Europe. However, the biggest and the most important is so called "Ukrainian question", or "Ukrainian crisis" which started at the end of 2013 after the declaration of Ukrainian government the Government refusal statement of signing the agreement on Ukraine-European Union Association Agreement. This decision of Ukrainian President and Government caused mass rioting and mass protest campaign inside Ukraine society during the winter 2013-2014. In Ukraine, this period was also called as a Revolution of Dignity. As the result of protests, Russia-friendly President of Ukraine Viktor Yanukovych was dismissed. Nevertheless, the Revolution of Dignity was made by Ukrainians and it is difficult to tell about if there was any foreign interference in organizing this political and social event. However, it is also important to underline the fact, that US neglected the main principle of international relations - the principle of non-interference in internal affairs of another country. Some of those actions were directly aimed to support protesters. For example, on $11^{\text {th }}$ December 2013 Assistant Secretary of State visited Kiev and actually even encouraged protesters. This kind of action is specific because such high-level representative visited mass riots, which were called illegal by Ukrainian officials at that time.

Nevertheless, even being limited in text and evidences, it is possible to make several conclusions, which directly show specific issues of American foreign policy towards Ukraine. For the first, different political American scientists and politicians marked an important and specific role of Ukraine in European international political, geographical and geopolitical spheres. They also underlined the role of Ukraine as a tool of opposing Russia in the region and spreading the influence of 
Asian Journal of Research

№ 2 (2), March 2017 www.journalofresearch.asia

info@journalofresearch.asia

United States on the areas, which always were vital national interests for Russia. For the second, practical direction of extension of American influence on post-Soviet space (Ukrainian in this case) in several areas:

1.The use of different tools of "soft power" like economic tools or use mediators like European Union or North Atlantic Treaty Organization for Ukraine, while this organizations are actually influenced by the USA.

2. "Hard power" tools like, melding into Ukrainian's internal political affairs during end of 2013 - beginning of 2014.

3.Issuing specific documents, which are able to an indirect influence on Ukrainian inner and foreign policy issues.

Specific issues of Russian foreign policy, which influenced Ukraine during the end of 2013 - first part of 2014 year

Russian political community has a bundle of traditions, which were inherited from the political school of Soviet Union. One of this "traditions" is an attempt to save former republics in the sphere of influence of Russian Federation, which was an official international successor, who inherited international obligations from former Soviet Union. The specific of international policy is an intention to make Russia a center of former Soviet republics, which separated and became independent international actors, for example Ukraine. One of these attempts was Russian initiative to create a new international organization, which would consist of former Soviet Republics. This organization was aimed to save the political connection among former Soviet Republics, while saving economic connections between countries. At the same time, it was more free that former Soviet Union and did not 
influence the sovereignty of any country. That was an attraction for many countries. However, Ukraine chose another way of its development and political orientation, and from the first days of independence aimed its way to move in the direction of European community, because the way of coming back to East wasn't attractive for Ukraine, first of all because of economic reasons, and of course because of American and European influence. In 1990th Russia, itself went through many financial, political and social challenges and faced the First Chechen War. The fact of war made Russian President and government concentrate all efforts on North Caucasus and Chechen directions, because separation of one republic was able to stimulate further fragmentation of Russian Federation and intensification of contradictions inside Russia, which remained to be a federation. Nevertheless, during $90^{\text {th }}$ political cooperation was not that active and successful, however economic heritage of Soviet Union reminded itself with strong economic interconnections between former Soviet republics. As far as strong connections between production capacities of republics, for example, for production of agricultural facilities in Ukraine, the production facility needed components from 5 or 6 former Soviet republics. This example is one of numerous cases, which shows deep interconnections of former Soviet republics. There are many other facts that make connections between Ukraine and Russian stronger:

- Very similar cultural identity;

- Common historical heritage;

- Interpersonal relations (mixed families which often consist from ethnic Ukrainian and Russian people); 
Asian Journal of Research

№ 2 (2), March 2017 www.journalofresearch.asia

info@journalofresearch.asia

- Mutual perception of Russian and Ukrainian people as fraternal nation (before Ukrainian Crisis).

Another fact, which attracts attention, is specific relations between Ukraine and Russia within oil-gas sphere. Russia is traditionally one of the most important European and Ukrainian oil and gas suppliers; however, Ukraine also plays a specific role in those relations because of importance of its gas pipeline network, which is used for transportation gas from Russia through Ukraine to Europe. In some cases, Ukrainian government tried to use this fact for pushing Russia to provide political and economic benefits, especially in cases of changing foreign policy orientation, as it happened after the "Orange Revolution" in Ukraine during so-called "Gas Wars" on 2005-2006 and 2008-2009. At that time, the new President of Ukraine Victor Yushchenko, whose election was actually a result of "Orange Revolution", decided to boost rapprochement of Ukraine with NATO and European Union. These actions of Ukraine could not but caused specific reaction of Russian Federation, which used economic tools for gaining political result, raising the price on gas for former Soviet republics. In some cases this tool was useful for gaining specific results, however at the same time showed a strong political will of Russian Federation to keep Ukraine close to Russia in all senses. Of course, these events caused harsh criticism from US and some European countries, but were not able to change position of Russian Federation.

However, this paper is aimed to focus on Ukraine as an international actor with specific geopolitical location, which is actually a point of collision between Russia and Ukraine. It is also necessary to give 
a brief introduction of general features of Russian foreign policy transformation during the period since 1991 and until now. All this period from historical perspective could be divided into several periods:

- 1992 - 1996 - many historical scientists call this period an American-Russian honeymoon, because even though Russian intentions to influence Russia's neighboring states can be called an imperial. However, at that time Russian leaders clearly understood that the main tasks were saving the key role of Moscow in inner Russia policy and preventing further disintegration. The rest of efforts were aimed on prevention of appearing of new post-Soviet countries, which might have nuclear weapons, in order to safe sole priority for having that kind of weapons in the region. In general, it was a period of adaptation in new international conditions for Russian leaders and political elites.

- 1996 - Beginning of 2000th. Due to changes of political leadership in the country, changed the vision of Russia, as a part of the international community and Russian role in the region during this period. Growing economic potential stimulated development of foreign and inner policy. At the same time, Russia started active cooperation within Commonwealth of Independent States, trying to involve other countries into this process. Russian officials also started to question the existing role of NATO, and even criticize it, because of its spreading on Eastern direction closer to the borders of Russia. Nevertheless, terrorist attacks on 9/11 made Russia and Western countries closer in some questions, but Russian political leaders and elites clearly understood that this period would pass soon. 
- Second part of first decade of $2000^{\text {th }}$ - until now. This period can be described as a period when Russia directly opposed US in Europe and questioned some issues of American foreign policy. For example, the placement of American missile-defense systems in Eastern Europe, active involvement of Ukraine and Georgia into different programs, considering expansion NATO closer to Russian borders. Russian foreign policy in some issue became even aggressive, for example RussoGeorgian War during August 7-12, 2005, and of course Ukrainian crisis.

Ukrainian Crisis, which started at the end of 2013, showed the real intentions of main international actors. For US it was a possibility to gain specific geopolitical benefits while using unstable social and economic situation in Ukraine, for Russia, which did not took part in the crisis at the very end. However, when the pro-Russian President of Ukraine Victor Yanukovych left the country and the situation went out of control. Russian special forces used power vacuum and blocked all the important objects on Crimea peninsula, and in a couple of weeks Crimea peninsula became a part of Russia.

Crimea remains to be a strategic point of Russia because of several reasons. First, because of the Russian Black Sea Navy Fleet presence in the region, this guarantees influence all over Black Sea Region. The second is - NATO spreading into the East direction, which usually was understood by Russian leaders as a threat. The third is strong historical and cultural connection of Crimea peninsula with Russian Federation. Fourth is to show political will and possibility to protect Russian national interests even if a threat for those interests is not direct. All this factors were important for taking decision of changing territorial 
allegiance of Crimea and starting openly oppose US and some European countries.

\section{Conclusions}

Collisions between big international actors first always influence smaller international actors, which become a collision points and points of high tension inside international community. Usual aim of the big actors can be divided into two groups: gaining or saving international influence. Speaking about Ukraine it is obligatory to say that Ukraine is specifically attractive for both groups of interests. At the same time, Ukrainian crisis demonstrates another important feature of international relations - polarization of international society, attempts of the USA to remain the only big and global power, even though many actors try to challenge US and re-establish former capabilities, what actually Russian Federation tries to do.

It is also interesting to notice that the Ukrainian crisis looks like a close copy of Arab spring, starting actually from social and economic factors, which provoked riots and finishing with results of revolution. However, in case of Ukraine there was creators of Ukrainian crisis did not consider one more fact - this fact was Russian national interests. Russia has enough resources to protect these vital national interests, at least close to its own borders. Especially given the discontent of Russia with the deployment of elements of U.S. missile defense system along the Western Russian border and the spread of NATO, which is a real military threat to Russia's national interests. Annexation of Crimea in this situation of destabilization on Russian border was the only way not to allow Western countries to finish intervention into Russian vital space. 


\section{References}

1.Edward Lucas and A. Wess Mitchell, Central European Security After Crimea: The Case for Strengthening NATO's Eastern Defenses, Center for European Policy Analysis Report No. 35 March 25, 2014, accesed

on http:/ /cepa.org/sites/default/files/The\%20Case\%20for\%20Strengtheni ng\%20NATOs\%20Eastern \%20Defenses-\%20\%282\%29.pdf

2. Eve Hunter with Piret Pernik, The Challenges of Hybrid Warfare, International Centre for Defence and Security, Tallinn, Estonia, accessed on

https://www.icds.ee/fileadmin/media/icds.ee/failid/Eve_Hunter_Pi ret_Pernik_-_Challenges_of_Hybrid_Warfare.pdf

3.Huntington, Samuel P., The Clash of Civilizations and the Remaking of World Order, New York, Simon \& Schuster, 1996 ISBN 0684-84441-9.

4. Marvin Kalb, “The Israeli-Hezbollah War of 2006: The Media as a Weapon in Asymmetrical Conflict," Faculty Research Working Paper RWP07-012, John F. Kennedy School of Government, Harvard University, February 2007, p. 4.

5. Michael Kofman and Matthew Rojansky, A Closer look at Russia's "Hybrid War", Wilson Center, accessed https:/ / www.wilsoncenter.org/sites/default/files/7KENNAN\%20CABLE-ROJANSKY\%20KOFMAN.pdf 
6. Nicu Popescu, Hybrid tactics: neither new nor only Russian, European Union Institute for Security Studies, January 2015, accessed on http://www.iss.europa.eu/uploads/media/Alert_4_hybrid_warfare.pd $\mathrm{f}$

7. William C. Potter, The Politics of Nuclear Renunciation: The Cases of Belarus, Kazakhstan, and Ukraine, Washington, DC: The Henry L. Stimson Center, 1995.

8.Zbigniew Brzezinski, Strategic Vision: America and the Crisis of Global Power, Basic Books, 2012. ISBN 978-0-465-02954-9.

9.Zbigniew Brzezinski, The Grand Chessboard: American Primacy and Its Geostrategic Imperatives, Basic Books, 1997, ISBN 0-465-02725-3 
Asian Journal of Research

№ 2 (2), March 2017 www.journalofresearch.asia

info@journalofresearch.asia

\section{Author information}

\section{Dmytro Butrsev,}

PHD Candidate, Central China Normal University

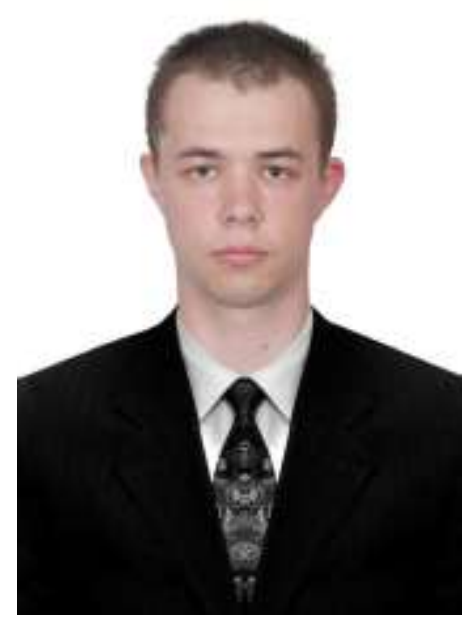




\section{Bazarova Dildora Bahadirovna}

Ph.D, associate professor at Tashkent state university of law

\section{SUBSTANCES AND MEANING OF THE CONCEPT OF STATE PROTECTION OF PARTICIPANTS OF THE CRIMINAL PROCESS}

In the article, the author considers in detail the content and significance of the concept of state protection of participants in criminal proceedings. Particular attention is paid to the legal and institutional aspects of the organization of state protection of participants in criminal proceedings in foreign countries (USA, European Union and CIS countries). Prospective directions of the further development of the considered direction of activity of the state, incl. Law enforcement bodies and improvement of the current domestic legislation.

Keywords: concept, state protection, criminal process, criminal proceedings, participants in criminal proceedings, state program, witness protection program, security measures, organized crime, witness, victim, witness protection units.

\section{СОДЕРЖАНИЕ И ЗНАЧЕНИЕ КОНЦЕПЦИИ ГОСУДАРСТВЕННОЙ ЗАЩИТЫ УЧАСТНИКОВ УГОЛОВНОГО ПРОЦЕССА}

Аннотация: В статье автор подробно рассматривает содержание и значение концепции государственной защиты участников уголовного процесса. Особое внимание уделено правовым и институциональным аспектам организации Social Sciences and Humanities

42 Generalization of Scientific Results 
Asian Journal of Research

№ 2 (2), March 2017 www.journalofresearch.asia info@journalofresearch.asia

государственной защиты участников уголовного процесса в зарубежных странах (США, страны Европейского союза и СНГ). Определены перспективные направления дальнейшего развития рассматриваемого направления деятельности государственных, в т.ч. правоохранительных органов и совершенствования действующего отечественного законодательства.

Ключевые слова: концепция, государственная защита, уголовный процесс, уголовное судопроизводство, участники уголовного процесса, государственная программа, программа защиты свидетелей, меры безопасности, организованная преступность, свидетель, потерпевший, подразделения защиты свидетелей.

Дальнейшая демократизация и либерализация судебноправовой системы, повышения эффективности деятельности судебных и правоохранительных органов, повышения доверия населения к правосудию, обеспечения надежной защиты прав и свобод граждан, укрепления верховенства закона и законности в обществе является основными приоритетами государственной политики.

Одним из важнейших факторов процветания и прогресса страны является состояния защищенности ее граждан, что неразрывно связано с гарантиями защиты прав и интересов человека. За годы независимости в Республике Узбекистан принят ряд актов законодательства, направленные на обеспечения верховенства закона, законности и правопорядка в обществе. 
Достаточно сказать, что в Государственной программе «Год диалога с народом и интересов человека», принятой в соответствии со Стратегии действий, более 60 мероприятий, направлено на обеспечение независимости судебной власти и усиление гарантий надежной защиты прав и свобод граждан.

В этом контексте все больше актуальность приобретает реализация задач уголовного процесса, в т.ч. укрепления законности, предупреждения преступлений, защита интересов личности, государства и общества, полное раскрытие преступлений и изобличение виновных. В этой системе особое место занимает защита участников уголовного судопроизводства, способствующих раскрытию преступления и наказанию преступников от применения насилия, подкупа и угроза, что является важнейшей задачей государства. Так как вероятность противоправных посягательств на участников процесса возрастает в зависимости от тяжести преступного деяния, а его эффективность повышается, если они осуществляются несколькими лицами ${ }^{19}$.

Вместе с тем, для создания эффективной системы защиты участников уголовного судопроизводства необходима разработка единой концепщии защиты, которая, направлена на выработку единого и целостного подхода к решению данной проблемы и в виде доктринальной системы определяет наиболее концептуальные направления института защиты участников уголовного судопроизводства. Содержание концепции составят деятельность

19 Зайцев О.А. Проблемы государственной защиты участников уголовного судопроизводства / / Союз криминалистов и криминологов. - 2014. - №3-4. - С.264. 
Asian Journal of Research

№ 2 (2), March 2017 www.journalofresearch.asia

info@journalofresearch.asia

государственных органов по разработке и реализации мер государственной защиты участников уголовного процесса, ее тенденции и закономерности, особенности расследования некоторых категорий преступлений, научно-теоретические и практические решения проблемы защиты указанных лиц.

Вместе с тем, как справедливо отмечает О.А.Зайцев, необходимость разрешения комплекса фундаментальных теоретических и прикладных проблем государственной защиты участников уголовного судопроизводства, требует доктринального толкования в условиях проведения правовой реформы ${ }^{20}$. Исходя из этого можно сказать, что слово «концепция» (лат. conception понимание, система) определяется как «система взглядов на чтонибудь, основная мысль», «определенный способ понимания, трактовки каких-либо явлений», «основная точка зрения, руководящая идея, ведущий замысел, конструктивный принцип различных видов деятельности» 21.

Концепцию обеспечения безопасности личности в сфере уголовного судопроизводства, по мнению А.Ю.Епихина, следует понимать, как систему научных взглядов, определяющих цель обеспечения безопасности личности, целесообразные средства ее достижения, основной инструментарий (понятийный аппарат,

\footnotetext{
20 Зайцев О.А. Концепция государственной защиты участников уголовного судопроизводства в Российской Федерации // Вестник Оренбургского государственного университета. - 2006. - №3. - С. 77-81.

${ }^{21}$ Епихин А.Ю. Обеспечение безопасности личности в уголовном судопроизводстве. M.: Litres, 2017.
}

Social Sciences and Humanities

45 Generalization of Scientific Results 
методики исследования и т. п.), сформированную для разрешения проблемы или описания (истолкования) имеющихся теоретических или эмпирических познаний 22.

Правоотношения, которые возникают, изменяются и прекращаются в связи с обеспечением мер государственной защиты и безопасности участников уголовного судопроизводства, многогранны 23 . Исходя из этого, в теории учеными дается разные толкования К понятию государственной защиты участников уголовного судопроизводства и его концепции. Так, А.Б.Ширитов считает, что институт государственной защиты участников уголовного судопроизводства представляет собой элемент механизма обеспечения и защиты прав лиц, вовлекаемых в производство по уголовным делам, который реализуется в случае возникновения угрозы конституционным правам и свободам этих лиц в связи с их участием в уголовном процессе и реализуется посредством специфических мер защиты: личная охрана, охрана жилища и имущества; выдача оружия, специальных средств индивидуальной защиты и оповещения об опасности; временное помещение в безопасное место; обеспечение конфиденциальности сведений о защищаемом лице; перевод на другую работу (службу), изменение места работы (службы) или учебы; переселение на

\footnotetext{
22 Епихин А.Ю. Концепция обеспечения безопасности личности в сфере уголовного судопроизводства: Автореф. дисс. ... док-ра юрид. наук. - Н.Новгород, 2004. - С.23.

${ }^{23}$ Кравцова О.В., Блинова-Сычкарь И.В. О понятии защищаемого лица в уголовном судопроизводстве // Молодой ученый. - 2016. - №8.1. - С. 35.
} 
Asian Journal of Research

№ 2 (2), March 2017 www.journalofresearch.asia

info@journalofresearch.asia

другое место жительства; замена документов; изменение внешности ${ }^{24}$.

По мнению В.А.Гаужаева, под государственной защитой участников уголовного судопроизводства понимается осуществление предусмотренных законом мер безопасности по защите жизни, здоровья этих лиц, их имущества, а также принятие мер социальной поддержки этих участников в связи с осуществлением ими гражданского долга, участием в производстве по уголовному делу специально уполномоченными на то государственными органами 25 .

Создание эффективных законодательных, организационнотехнических и административных механизмов защиты участников уголовного судопроизводства является важным фактором формирования активной политики борьбы с преступностью, эффективного раскрытия преступлений, а также обеспечения национальной безопасности. Так как, эффективность расследования преступлений, в т.ч. заинтересованность граждан при оказании содействия правоохранительным органам напрямую

\footnotetext{
24 Ширитов А.Б. Правовое регулирование мер государственной защиты участников уголовного процесса: Автореф. дисс. ... канд. юрид. наук. - Краснодар, 2010. - С. 17.

${ }^{25}$ Гаужаева В.А. Использование псевдонима как одна из мер государственной защиты свидетелей и потерпевших на досудебных и судебных стадиях уголовного судопроизводства // Вектор науки ТГУ. Серия: Юридические науки. - 2015. - №1(20). C.14.
} 
зависит от степени защищенности лиц, содействующих уголовному судопроизводству ${ }^{26}$.

В этой связи важное значение приобретают вопросы правового регулирования государственной защиты лиц, содействующих уголовному судопроизводству. В последние годы усиливалось тенденция принятия законодательных мер, в том числе разработка процессуальных гарантий по защите участников уголовного судопроизводства и повышению их заинтересованности в участие в уголовном процессе. Так в современных условиях в большинстве зарубежных странах (США, Великобритания, Франция, Германия, Хорватия, Босния и Герцеговина, Сербия, Российская Федерация, Азербайджан, Казахстан, Украина и др.) приняты специальные законы в сфере государственной защите потерпевших, свидетелей и иных участников судопроизводства.

Так во Франции государственная защита участников уголовного судопроизводства осуществляется в соответствии с законами «О возмещении ущерба за телесный вред, причиненный потерпевшим преступлением» от 1977 года, «Об усилении безопасности и защиты свободы личности» от 1981 года и «Об усилении защиты жертв преступлений» от 1983 года. Во Франции функция по защите лиц, содействующих уголовному

\footnotetext{
26 См. подр: Дмитриева А.А. Переселение защищаемых лиц на другое место жительства: новое в применении меры государственной защиты // Вестник Томского государственного университета. Право. 2015. №2 (16). - С.37-44; Становление и развитие института государственной защиты (Историко-правовое исследование): монография / И.А.Горшенёва, А.В.Лукинский, Н.В.Михайлова; под ред. проф. Н.В.Михайловой. - М.: Русайнс, 2014. - 148 с.
} 
судопроизводству возложено на Бюро по делам жертв преступлений при Министерстве юстиции и Межминистерскому комитету, и Национальному институту помощи жертвам и посредничества $(\text { (ИHABEM })^{27}$.

В Германии вышеуказанные вопросы урегулированы Законом «О регулировании вопросов обеспечения защиты свидетелей, которым угрожает опасность» от 1998 г., Концепции и Общие указания федеральных и земельных министров юстиции и внутренних дел по охране находящихся под угрозой свидетелей от 1990 г. В соответствии с указанной Концепцией при уголовной полиции земель и федеральном управлении уголовной полиции стали создаваться координационные пункты охраны свидетелей, призванные определять специфические меры охраны и после включения свидетеля в программу защиты обеспечивать их безопасность ${ }^{28}$.

В США обеспечения защиты свидетелей возлагается на Службы маршалов, в которой четко организовано специализация сотрудников при осуществлении защитных мероприятий ${ }^{29}$. Разрабатывая программу защиты свидетеля, Служба маршалов в каждом конкретном случае определяют необходимые меры защиты и разрабатывают его процедуру для применения.

27 Рыжаков А.П. Комментарий к правилам защиты сведений об осуществлении государственной защиты потерпевших, свидетелей и иных участников уголовного судопроизводства // Система КонсультантПлюс.

28 http://www.gumer.info/bibliotek_Buks/Pravo/batur/30.php

29 The 1993 organizer's Guide to National Crime Victims Rights Week. Washington. 1993. p. 20. 
Необходимо отметить, что в США система защиты участников уголовного судопроизводства не является исключительной прерогативой лишь одного государственного органа. В США она является многоуровневой, т.е. в ней участвуют как федеральные органы власти, так и органы власти штатов и отдельных муниципальных образований. При этом наблюдается не столько «разграничение», сколько «объединение» полномочий в данной области. Так, непосредственно Маршальская служба выполняет преимущественно «техническую» сторону деятельности, т.е. непосредственно осуществляет мероприятия, направленные на обеспечение безопасности конкретного лица. Жилые помещения для переселения свидетеля (иного участника процесса), его семьи выделяют преимущественно власти штатов. Органы власти графств и отдельных городов решают вопросы трудоустройства таких лиц, оказания им психологической и иной помощи ${ }^{30}$.

В странах Европейского Союза, как правило, принята национальная либо федеральная программа по защите свидетелей. Так некоторые страны ЕС, таких как, Великобритания, Германия и Испания принимают также региональные или местные программы. Круг преступлений, в связи, с совершением которых применима защита свидетелей также варьируется от страны к стране. Так, в Бельгии и Италии меры защиты применяются в случае совершения специфических преступлений (дела, касающиеся наркотиков, деятельности мафии или

\footnotetext{
30 Кондратьев Е.Е. Пути решения проблемы защиты свидетелей // Право и безопасность. - 2004. - №1(10).
}

Social Sciences and Humanities

50 Generalization of Scientific Results 
умышленных убийств либо любого преступления, наказываемого лишением свободы на срок от 5 до 20 лет). Некоторые страны пошли по пути включения в свои программы исчерпывающего списка преступлений (Румыния), а другие упоминают только о «тяжких» или «серьезных» преступлениях (Литва), организованной преступности (Венгрия) либо не упоминают о конкретных преступлениях вовсе, что дает право участия в программе свидетелям преступлений любого рода (Словакия, Словения) $)^{31}$.

В Российской Федерации приняты законы «О государственной защите судей, должностных лиц правоохранительных и контролирующих органов» (20 апреля 1995 г. № 45-Ф3) и «О государственной защите потерпевших, свидетелей и иных участников судопроизводства» (20 августа 2004 года № 119-Ф3), в которых установлены принципы осуществления и виды государственной защиты, включающие меры безопасности и социальной поддержки, определены органы, обеспечивающие государственную защиту, и порядок применения мер 32.

Итак, по итогам изучения зарубежного законодательства, хотелось бы отметить следующие:

Первое. С учетом передового зарубежного опыта предлагается принять Закон Республики Узбекистан «О государственной защите

31 Краснова К.А. Защита свидетелей в государствах-членах ЕС // Международное право. - 2015. - №4. - С.68.

32 Ширитов А.Б. Правовое регулирование мер государственной защиты участников уголовного процесса: Автореф. дисс. ... канд. юрид. наук. - Краснодар, 2010. - С. 17. 
потерпевших, свидетелей и иных участников судопроизводства», предусматривающая видов государственной защиты, оснований и порядок осуществления государственной защиты, права и обязанности защищаемых лиц и органов, обеспечивающих государственную защиту, финансовое и материально-техническое обеспечение государственной защиты и др.

В этой связи важным является своевременная и качественная реализация положений Указа Президента Республики Узбекистан «О мерах по дальнейшему реформированию судебно-правовой системы, усилению гарантий надежной защиты прав и свобод граждан» от 21 октября 2016 года, в которой предусмотрено разработка аналогичного законопроекта, предусматривающего обеспечение государственных гарантий по физической и социальной защите потерпевших, свидетелей и иных участников уголовного процесса.

Второе. В уголовно-процессуальном законодательстве следует отдельной нормой предусмотреть меры обеспечения безопасности правового, социального, экономического, физического, организационного и информационного характера. Так в качестве мер государственной защиты участников уголовного судопроизводства предлагается включить разработка программы защиты свидетелей, скрытия информации об участниках программы и установления санкций за неправомерное разглашение такой информации, установление совокупности прав и обязанностей, защищаемых лиц при применение мер государственной защиты, изменение места работы (службы) или 
Asian Journal of Research

№ 2 (2), March 2017 www.journalofresearch.asia

info@journalofresearch.asia

учебы, переселение на другое место жительства, замена документов и др.

Третье. В настоящее время возникает необходимость внесение в действующем уголовно-процессуальном законодательстве отдельную норму, предусматривающую правовой статус защищаемого лица, его права и обязанности, а также перечень мер государственной защиты, основания для их применения, перечень лиц, подлежащих государственной защите, обстоятельства, позволяющие раскрыть информацию о защищаемом лице. 
Asian Journal of Research

№ 2 (2), March 2017 www.journalofresearch.asia

info@journalofresearch.asia

\section{Author information}

Bazarova Dildora Bakhadirovna

Since 2014: Independent researcher of the Tashkent State Law University,

Since 2011: Associate professor at departament criminalistics in

Tashkent State Law University,

Date of birth: 05/02/1976

Birthplace: Tashkent region, Tashkent city

Nationality: Uzbek

Education: The highest

I have ended 1998 Tashkent State Law Institute

Specialty by training: lawyer

Academic degree: Candidate of juridical sciences $(\mathrm{PhD})$

Academic status: Associate professor

Interests - criminal procedure law, criminalistics.

Theme of research: «Procedural guarantees of the rights of participants in criminal proceedings: theory and practice»

Summary of publications: 15 textbook and manuals, other 60 articles. 


\section{ASKING QUESTIONS AND ELICITING}

\section{Nargiza Khodjaqulova Khosiyatqulovna}

A senior teacher of the foreign languages department, Tashkent University of Information Technologies, Tashkent, Uzbekistan nargiza.khodjaqulova@mail.ru

Abstract: In this article, asking questions and eliciting have been analyzed. As it is known, there are different types of learners according to physical and psychological approach. These are designed to elicit learners' prior knowledge and to check comprehension. They often focus on the form or meaning of language structures and items, and the teacher already knows the answer.

Key words: teaching, foreign languages, learning style, visual, auditory, tactile, kinaethetic, ESL, strategy, interact, preferences

Teaching is more about asking the right questions than answering them. ${ }^{33}$

Asking questions is a natural feature of communication, but also one of the most important tools, which teachers have at their disposal.

Questioning is crucial to the way teachers manage the class, engage students with content, encourage participation and increase understanding. ${ }^{34}$

\footnotetext{
33 Rod Bolitho, Professional Development for Uzbekistan English Teachers. 2009. P.138-139

34 Gabrielatos, C. A Question of Function: Teacher Questions in the EFL Classroom. 1997.http:/ / www.gabrielatos.com

Social Sciences and Humanities

55 Generalization of Scientific Results
} 
There have been a number of typologies and taxonomies of questions. Socratic questioning, exemplified by Paul's taxonomy, forms the basis of eliciting, while Bloom's taxonomy identifies six types of questions by which thinking skills may be developed and tested. In the context of language teaching and learning, Bloom himself maintained that; "The major purpose in constructing a taxonomy of educational objectives is to facilitate communication..." Classroom questions tend to fall into two broad categories: 35

Display questions. These are designed to elicit learners' prior knowledge and to check comprehension. They often focus on the form or meaning of language structures and items, and the teacher already knows the answer.

- What does ..... mean?

- When do we use .....?

-What comes after .....?

-What's the opposite of .....?

- Where's the stress in .....?

Referential questions. These require the learner to provide information, give an opinion, explain or clarify. They often focus on content rather than language, require 'follow-up' or 'probe' questions, and the answer is not necessarily known by the teacher.

-What do you think about .....?

- Have you ever....when/where .....?

- If you had ......what.....?

- What kind of .....? 
Asian Journal of Research

№ 2 (2), March 2017 www.journalofresearch.asia

info@journalofresearch.asia

- How do you .....?

The best referential questions are those that are 'divergent' or 'open-ended' in that they are broad, may have multiple answers, and require a higher level of thinking from the learners.

Open-ended questions are ideal for developing skills such as inferring, predicting, verifying and summarising, as well as eliciting more language. 'Convergent' or 'closed' questions have more narrowly defined correct answers which can be recalled from memory and require little reflection or originality. Closed questions are common in conventional tests.

In this article we will also discuss what Eliciting is. As it is known there are some close meanings in dictionaries such as "searching", "drawing out", "discovering", "realizing", "understanding".

The whole point of eliciting is to find out whether someone knows the correct answer. Some students may actually have a bigger vocabulary than others. If nobody can give the answer it is a signal to the teacher that she should introduce the word or words which are needed to answer the question. By trying to elicit the needed vocabulary first teachers can make the class listen with more interest.

Eliciting is a technique used by the teacher during the lesson that involves the language learner in the process of discovering and understanding language. Anything in the lesson can be elicited: vocabulary, grammar, experiences, and ideas. The objective of eliciting is to allow the learners the chance to participate in the learning process by letting them express their acquired or intuitive knowledge, and through 
critical thinking which will enhance their language abilities by adding to what they already know. ${ }^{36}$

The key to successful eliciting lies in an artful interaction between the teacher and the learner. There is no special time for eliciting to occur during the lesson. It can be used as needed-during any of the engage, study and activate sections of the lesson.

Elicit from participants or tell them that first you said an unfinished sentence to elicit the word. During the lesson, a teacher gives a short prompt and elicits a long answer. Another form of eliciting is the demonstration a teacher mimes the action to get the students to produce a verb. It should be emphased that eliciting is really only suitable for 'closed'-type information, when the teacher is 'fishing' for a particular answer.

When teachers ask students, questions they should start with easy questions and then move on to more difficult ones. It is not enough to ask questions, which develop, only lower order-thinking skills; teachers should ask questions, which require higher order thinking skills. Moreover, elicitation is important because it gives a teacher information about how much and what exactly students know. Besides, elicitation is also motivating for students because it gives them a chance to be actively involved in a lesson. It can also be a more entertaining and memorable way to learn.

Here some tips for eliciting from British Council website; ${ }^{37}$

\footnotetext{
36 Rod Bolitho, Professional Development for Uzbekistan English Teachers. 2009. P.138-139

37 Steve Darn, Freelance Trainer, Izmir, Turkey, Funda Çetin, Izmir University of Economics. https://www.teachingenglish.org.uk/article/eliciting
} 
$\checkmark \quad$ Eliciting is a basic technique and should be used regularly, at not only the beginning of a lesson but also whenever it is necessary and appropriate.

$\checkmark \quad$ Do not try to 'pull teeth'. Prolonged silence or incorrect answers suggest that input is required from the teacher.

$\checkmark \quad$ Do not ask students to repeat incorrect answers, but ask a variety of students to repeat a good answer.

Acknowledge or give feedback to each answer with gestures or short comments.

$\checkmark \quad$ Provide sufficient context or information. Eliciting differs from Socratic questioning in that it is designed to find out what the learners know rather than to lead them to a conclusion, which only the teacher knows.

$\checkmark \quad$ Learners can elicit from each other, particularly during brainstorming activities. This helps to build confidence and group cohesion as well as shifting the focus away from the teacher.

At lower levels, more guided questioning is needed. Openended questions should be avoided, as the learners are unlikely to have the language to answer them to their own satisfaction.

\section{Why ask questions?}

Teachers ask questions for a variety of purposes, including:

- To actively involve students in the lesson

- To increase motivation or interest

- To evaluate students' preparation

- $\quad$ To check on completion of work

- $\quad$ To develop critical thinking skills 
Asian Journal of Research

№ 2 (2), March 2017 www.journalofresearch.asia

info@journalofresearch.asia

- To review previous lessons

- To nurture insights

- To assess achievement or mastery of goals and objectives

- To stimulate independent learning

A teacher may vary his or her purpose in asking questions during a single lesson, or a single question may have more than one purpose.

In general, research shows that instruction-involving questioning is more effective than instruction without questioning. Questioning is one of the nine research-based strategies presented in Classroom Instruction That Works (Marzano, Pickering, and Pollock 2001).

One important finding is that questions that focus student attention on important elements of a lesson result in better comprehension than those that focus on unusual or interesting elements. Questions should also be structured so that most elicit correct responses.

\section{Types of questions}

Educators have traditionally classified questions according to Bloom's Taxonomy, a hierarchy of increasingly complex intellectual skills. Bloom's Taxonomy includes six categories:

$\checkmark \quad$ Knowledge - recall data or information

$\checkmark$ Comprehension - understand meaning

$\checkmark \quad$ Application - use a concept in a new situation

$\checkmark \quad$ Analysis - separate concepts into parts; distinguish between facts and inferences

$\checkmark \quad$ Synthesis - combine parts to form new meaning 
$\checkmark \quad$ Evaluation - make judgments about the value of ideas or products $^{38}$

Some researchers have simplified classification of questions into lower and higher cognitive questions. Lower cognitive questions (fact, closed, direct, recall, and knowledge questions) involve the recall of information. Higher cognitive questions (open-ended, interpretive, evaluative, inquiry, inferential, and synthesis questions) involve the mental manipulation of information to produce or support an answer. ${ }^{39}$

Regardless of the classification, traditional wisdom holds that the higher cognitive questions lead to higher-quality answers and increased learning and achievement. However, the research has mixed conclusions in this area. Some studies found that higher-level questions did indeed produce deeper learning, while others found that not to be the case.

According to some studies, lower cognitive questions (knowledge and comprehension on Bloom's Taxonomy) may be most beneficial for primary students. Lower cognitive questions are also more effective when the goal is to impart factual knowledge and commit it to memory.

Higher cognitive questions (application, analysis, synthesis, and evaluation) should make up a higher percentage of questions asked above the primary grades. Studies show that a combination of lower and higher questions is more effective than the exclusive use of one or the other. Increasing the use of higher cognitive questions can produce superior learning gains for older students, particularly those in

38 Cotton, K. 1989. Classroom questioning. School Improvement Research Series. Northwest Regional Educational Laboratory. http://www.nwrel.org/scpd/sirs/3/cu5.html.

39 Marzano, R., D. Pickering, and J. Pollock. 2001. Classroom instruction that works: Research-based strategies for increasing student achievement. Alexandria, VA: Association for Supervision and Curriculum Development. 
secondary school, and does not reduce student performance on lower cognitive questions.

It is important to note, though, that simply asking these kinds of questions does not guarantee higher responses or greater learning gains. Students need explicit instruction in answering these types of questions, including making inferences. This instruction, in conjunction with the use of higher cognitive questions, can positively influence student achievement.

\section{How many questions? When?}

How many questions should a teacher ask? In addition, at what point during the lesson? Frequent questioning has been shown to be positively related to learning facts, but simply asking a greater number of questions does not facilitate the learning of more complex material. Just as with higher cognitive questions, it may be necessary to include explicit instruction to promote student learning of complicated concepts.

Teachers often pose questions prior to reading. Research shows that while this strategy is effective for older students, those with high ability, and those interested in the subject matter, it is not as effective for younger students and poor readers, who tend to focus only on the material that will help them answer the questions.

\section{Wait-time}

Wait-time is another crucial factor in questioning techniques. Waittime can be defined as the amount of time a teacher allows to elapse after he or she has posed a question. (A less frequently used and researched definition is the amount of time that a teacher allows to elapse before responding after a student stops speaking.) While traditional wisdom 
Asian Journal of Research

№ 2 (2), March 2017 www.journalofresearch.asia

info@journalofresearch.asia

advocates a brisk pace of instruction to maintain interest and cover more material, research shows that slowing slightly to include more wait-time promotes achievement.

\section{Conclusion}

The success of eliciting depends largely on the attitudes of teachers and learners to their respective roles. Ideally, it promotes the notion of an exchange of information, helps to break down traditional teachercentredness, and begins to establish a variety of interaction patterns in the classroom. It is also fundamental to the inductive approach to teaching language and to learning through tasks and self-discovery, and a simple and effective way of getting learners to produce language.

\section{References}

1. Bloom, B.S. Taxonomy of Educational Objectives. Addison Wesley, 1956

2. Cotton, K. 1989. Classroom questioning. School Improvement Research Series. Northwest Regional Educational Laboratory. http://www.nwrel.org/scpd/sirs/3/cu5.html.

3. Gabrielatos, C. A Question of Function: Teacher Questions in the EFL Classroom. 1997.http:/ / www.gabrielatos.com

4. Marzano, R., D. Pickering, and J. Pollock. 2001. Classroom instruction that works Research-based strategies for increasing student achievement. Alexandria, VA: Association for Supervision and Curriculum Development. 
Asian Journal of Research

№ 2 (2), March 2017 www.journalofresearch.asia

info@journalofresearch.asia

5. Rod Bolitho, Professional Development for Uzbekistan English

Teachers. 2009. P.138-139

6. Steve Darn, Freelance Trainer, Izmir, Turkey, Funda Çetin, Izmir University of Economics.

https://www.teachingenglish.org.uk/article/eliciting

\section{Author information:}

\section{Khodjaqulova Nargiza Khosiyatqulovna}

Academic title PhD, MA etc. A senior teacher of English language

Name of University, Institution Company name, Country Tashkent University of Information Technologies

E-mail: nargiza.khodjaqulova@mail.ru

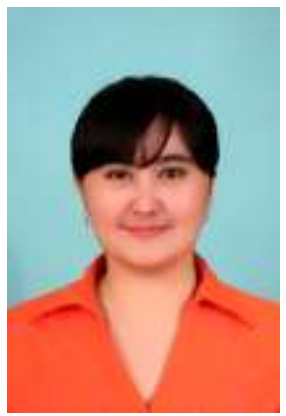




\section{Shukhrat Mashrabovich Mirzaev}

Master of Law, Senior Researcher Applicant of the Tashkent State University of Law of the Ministry of Justice of the Republic of Uzbekistan

\section{THE COORDINATION AS A WAY OF ORGANIZE OF LAW ENFORCEMENT ACTIVITY}

In this article author had searched the actual scientific and theoretical issues on the conception of the coordination as a way of organize of law enforcement activity well as its attributes, types. In the article author also had analyzed the problems of municipal administration's activity in this sphere and made his suggestions.

Key words: The law enforcement activity, coordination meeting, the attributes, public service, prosecuting authorities, municipal bodies, local authorities, Commissions for minors.

In general, as well as any other activity, law enforcement largely depends on the policy of the state that their actions can accelerate or slow down the legal process in the country. Thus the state regulation of the process of legal protection and the protection of citizens and legal persons from illegal encroachments, involves not only the activity of the central government, but also the public authorities in the field.

In particular, an important role in ensuring law and order in the relevant territory, along with law enforcement agencies, is the level of 
authority of the regions themselves to take certain operational decisions coordinating nature.

Coordination activities represented a kind of legal action, which is aimed at establishing the best possible relations between the different types (subspecies) of the power of the competent authorities in order to improve the efficiency and quality of performance of the tasks and functions and, based on this, to better meet the general social, group and individual needs and interests. This coordination is one of the internal resources of the state apparatus and in its simplest form is a streamlining of existing public bodies through the provision of their interaction.

Thus, the well-known American economists McConnell and Brue, analyzing the problems of cities, convincingly demonstrate that the impact of coordination processes can significantly enhance the effectiveness of a number of city services, citing as examples the police, fire department, urban development and public transport. ${ }^{40}$ By the point of view of many scientists, the coordination of law is inherent, since its primary purpose - to regulate social relations. ${ }^{41}$ Features of this feature is, inter alia, to coordinate social interactions. ${ }^{42}$ You could even say more: just law as a set of mandatory rules is in the state organized society, a unified system that seeks to coordinate, organize the actions of people.

\footnotetext{
${ }^{40}$ K.R. McConnell and S.L. Brue. The economics. - M. 1992. Ch.2 - P.271.

${ }^{41}$ For example: V.P. Kulapov. The genesis of state and law / the theory of state and law. Textbook. Under red.N.I. Matuzov and A.V. Malko. - M. 1997. - P.42.; V.S. Nersesianz. The philosophy of law. - M., 1999. - P.71, 83. L.I. Petrajitski. The theory of state and law in connection with the theory of morality. - StPb., 2000. - P.123, 131, 157-158, 165-166, 259, 445, 589.
}

${ }^{42}$ The theory of state and law. Textbook. Under red. V.K.Babaev. - M., 1999. - P.258

Social Sciences and Humanities

66 Generalization of Scientific Results 
At the same time, the variety of entities operating on the Prevention of Crime and the diversity of the activities put on the agenda the issue of coordination. It is of particular importance even in connection with the fact that the system of crime prevention entities involved state bodies and public organizations unrelated administrative subordination. ${ }^{43}$

Implementation of the measures of coordination among the subjects of prevention, non-subordination, perhaps on the basis of mutually agreed action without the use of administrative measures on the part of both one and the other authority, in strict compliance with their functional tasks. Given the nature of the functional tasks, conditions, actions of prevention actors, coordination forms are divided into the following groups.

a) Comprehensive administrative and territorial coordination. This type covers the whole system of preventive activity of subjects functioning in the conditions of the area, city, region and the whole country, which allows complex to implement a set of socio-economic, legal, ideological, educational, cultural and welfare and other measures for the coordination of prevention measures crimes and other offenses. For example, in terms of administrative and territorial units of work on the prevention of crime can also be carried out under the supervision of public authorities in the field in which to establish a permanent committee, coordinating the work of state bodies and public organizations engaged in prevention activities in their jurisdictions.

\footnotetext{
${ }^{43}$ V.A.Lisichkin. The theory and practice of prognostics. M., Nauka, 1972. - P. 63
} 
Thus, in accordance with Article 8 of the Law "On Prevention of Offences" maintenance of interaction of bodies and institutions directly involved and participating in crime prevention, in the relevant territory, it is the responsibility of public authorities in the field.

b) Subject-target coordination covers a certain range of coordination activities of subjects to achieve this goal in the system of crime prevention.

In this, kind of subjects are the coordination, such as:

- Commissions for minors - in relation to the activities of all government agencies and institutions, public organizations, labor collectives, self-government bodies designed to lead educational work among minors ${ }^{44}$;

- Supervisory commissions for the social adaptation of persons released from prison, overseeing educational work of these individuals and providing assistance in their employment, carry out work to prevent recidivism ${ }^{45}$;

c) intra-industry coordination and interior coordination carry out individual departments, organizations in the field, in functional tasks

\footnotetext{
${ }^{44}$ Commissions for minors create under khokimiates of districts, cities, regions and city of Tashkent, they are realized their powers and functions in accordance with the Law "On Prevention of Offences of minors" as well as the Regulation on Commissions for minors, adopted by the government of Uzbekistan.

${ }^{45}$ Supervisory commissions for the social adaptation of persons released from prison create under khokimiates of districts, cities, regions and city of Tashkent, they are realized their powers and functions in accordance with the Decree of President of the Republic of Uzbekistan "On perfecting of activity of centers of social adaptation" as well as the Regulation on this Commissions, adopted by the government of Uzbekistan.
}

Social Sciences and Humanities

68 Generalization of Scientific Results 
Asian Journal of Research

№ 2 (2), March 2017 www.journalofresearch.asia

info@journalofresearch.asia

include the implementation of crime prevention (internal affairs agencies, prosecutors, courts, etc.);

d) Inter-agency coordination - covers himself the activity of two or more subjects of prevention. For example, there are coordination meetings of law enforcement bodies (prosecutors, police, the National Security Service). For example, in accordance with the Laws of the Republic of Uzbekistan "On the prosecutor's office" (Article 8) and "On prevention of offenses" (Article 11) coordinating the activities of law enforcement agencies to combat crime, as well as bodies and institutions directly involved in the prevention of crime, carries Attorney General of the Republic of Uzbekistan and the procurators subordinate to him.

Taking into account the above, it should be noted that as the implementation of the country's legal and judicial and administrative reforms, the structuring of the law enforcement system, the specialization of its elements becomes more and more obvious need for the development of theoretical bases of law enforcement coordination.

We believe that the consolidation of State authority and efficiency of the state apparatus in the region can be achieved, primarily due to the hidden, internal resources of the system, in particular by streamlining the existing public authorities through a scientifically based concept of ensuring their cooperation. In the transition period coordination activities of particular political importance, because at this stage requires the greatest synergy of competent state bodies (their territorial and structural units) in the public administration in any sphere. An important place and role in this process should be assigned to the coordination of activities of state authorities in the field. 
Asian Journal of Research

№ 2 (2), March 2017 www.journalofresearch.asia

info@journalofresearch.asia

Formation of a civil society in Uzbekistan in the context of globalization and the rapidly changing modern world increases the responsibility of local authorities for the implementation of social and economic development of the country. First and foremost, this is explained by the fact that the system of their activity covers various aspects of society and involves solving the problems associated with ensuring the proper functioning of the regional economy, creation of conditions for development of social sphere, as well as the implementation of other important functions, which in turn depends on security the rule of law.

In this regard, to ensure law and order, protection of the rights and freedoms of man and citizen, protection of rights and legal interests of the state and non-governmental organizations and public associations, the fight against crime and other offenses - are among the key areas of activity.

There are fairly strong constitutional and other legal basis for the allocation of the special status of the state local authorities (councils of people's deputies and the executive authorities in the field) in the organization of regional work for the prevention of crimes and other offenses, including through the organization of cooperation and integrated administrative-territorial coordination of law enforcement and regulatory authorities.

In particular, in accordance with Article 100 of the Constitution of the Republic of Uzbekistan to the jurisdiction of local authorities, along with other powers concerns and to ensure law and order and security of citizens. According to Articles 102 and 104 of the Constitution of the 
Asian Journal of Research

№ 2 (2), March 2017 www.journalofresearch.asia

info@journalofresearch.asia

representative and executive authorities in the respective territory led areas governor, area and the city, which is within his authority to make decisions binding on all enterprises, institutions, organizations and associations, as well as officials and citizens on the relevant territory.

In accordance with Article 25 of the Law "On State local authorities" areas governor, area, city adopts measures relating to the observance of public order and fighting crime, citizens' security, the protection of their rights and health, organize the work of disaster relief, epidemics and other extreme cases, as well as solve other issues related to the laws of its jurisdiction to ensure law and order and security, protection of the rights and freedoms of citizens.

Thus, in accordance with Article 8 of the Law of the Republic of Uzbekistan "On crime prevention" measures aimed at ensuring the social protection of the population, to ensure law and order, protection of the rights and freedoms of citizens, as well as ensuring the interaction of bodies and institutions directly involved and participating in crime prevention, in the relevant territory is one of the main powers of public authorities on the ground in the area of crime prevention.

According to Article 6 of the Law "On protection of citizens' health" protection of human rights in the area of health, enforcement of health legislation the citizens, the implementation of measures aimed at saving lives and protecting their health in emergencies, to inform about the situation of citizens in the emergency area and the measures taken, coordination and control of bodies, institutions and enterprises of the health system, control over the quality of provided medical and social 
assistance to health institutions and a number of other powers are the responsibility of public authorities in the field.

The list of powers of the state to the local authorities in the field of law and order and security, protection of the rights and freedoms of citizens are detailed in the Laws of the Republic of Uzbekistan "On Road Traffic Safety", "On Combating Human Trafficking", "On Defense", "On Protection of Population and territories from emergency situations" and a number of other laws.

At the same time, giving the public authorities in the field with special powers in the field of law enforcement, it is necessary to establish an effective legal framework, regulating in detail the procedure for the implementation of public authorities in the field of functional tasks to ensure interoperability and an integrated administrative and territorial coordination of law enforcement and regulatory authorities.

So, hokims in their territory enable communication and coordinate within their competence, the activities of state bodies, institutions and organizations, non-profit organizations, including the self-governing bodies of citizens, usually by general guidance of permanent commissions. ${ }^{46}$

But, the lack of a legal mechanism regulating the procedure for the implementation of public authorities in the field of functional tasks to ensure cooperation and coordination of law enforcement and regulatory authorities, as well as lack of staff units (3-4 pers.) Group on law enforcement, the military mobilization and emergency regional

\footnotetext{
46 For example, we can see the commissions of minors, commissions of trafficking, commission on drug prevention and other.
} 
administrations, the absence of their units in the district and the city administration - in our opinion, may adversely affect the efficiency of public authorities in the field in this sphere.

An analysis of the problems in the sphere of interaction and complex administrative-territorial and inter-departmental coordination of law enforcement agencies believe it necessary to adopt a series of effective organizational and legal measures.

Firstly, the draft legal act is necessary to develop ("On law enforcement," such as the Act), which will provide:

- The concept of law enforcement, as well as its principles, goals, objectives and forms of implementation, the criteria for evaluating the effectiveness of these activities;

- Identifying the law enforcement agencies;

- Consolidation of the legal status of employees of law enforcement bodies, legislative framework of personnel policy in the system of data, including about promotion of employees, service discipline;

- The creation of a specific legal framework for the effective use of such forms of cooperation between law enforcement bodies and other bodies and non-governmental organizations such as the transfer of law enforcement documents and materials related to the competence of law enforcement agencies, including law enforcement officials in the commission, created on topical issues, inviting officials law enforcement officials at the meeting, board and other activities of other organs of the state, involving representatives of law enforcement bodies to control activities; 
- Consolidation of the rules, providing law enforcement an adequate level of social and legal protection.

Secondly, it is appropriate to abolish the existing commissions and councils under the Council of Ministers of the Republic of Karakalpakstan, regions and Tashkent city, district and city administration and form a permanent Coordination meeting of law enforcement, led by the Chairman of the Council of Ministers of the Republic of Karakalpakstan, the regional governor and the city of Tashkent, districts (cities).

In addition, we believe it appropriate vesting Coordination meetings right preparation of proposals and recommendations aimed at improving the legal regulation of law enforcement activities, if necessary, submit them for consideration to the Cabinet of Ministers and the President of the Republic of Uzbekistan.

Third, we believe that it is necessary to develop and implement a legal mechanism providing for the procedure for approval Jokargy Kenes of Karakalpakstan, regional, district (city) councils of people's deputies of the candidates nominated for the positions of heads of territorial divisions of law enforcement and regulatory authorities.

In addition, we believe it necessary to give the right to the Chairman Jokargy Kenes of Karakalpakstan, regional governor and the city of Tashkent right to initiate the issue of bringing to disciplinary responsibility of the heads of territorial divisions of law enforcement and regulatory authorities in the event of improper performance of his duties, by making mandatory for consideration of submissions to the higher authorities. 
Fourthly, it is advisable to set up on the basis of existing in the Council of Ministers of the Republic of Karakalpakstan, regions and the city Group of Tashkent on the activity of law enforcement bodies, military mobilization and emergency situations in the Council of Ministers of the Republic of Karakalpakstan, regions and Tashkent city, district and city administration of special departments (branches) on cooperation and coordination of law enforcement authorities.

We think that prompt consideration and adoption of the abovementioned organizational and legal measures will contribute to the democratization of the individual public administration, enhancing the role and responsibility of public authorities and local law enforcement agencies in the implementation conferred upon them by the Constitution and laws of the Republic of Uzbekistan authorities.

In addition, these measures will help to define a clear legal framework khokims functions, as well as to strengthen their role and importance in ensuring law and order and security, protection of the rights and freedoms of citizens in the regions.

\section{Author Information}

\section{Shukhrat Mashrabovich Mirzaev}

Master of Law, Senior Researcher Applicant of the Tashkent State University of Law of the Ministry of Justice of the Republic of Uzbekistan

Republic of Uzbekistan 100047. Tashkent city, Sayilgoh str., 35. E-mail: mirzaev-s@list.ru 
Asian Journal of Research

№ 2 (2), March 2017 www.journalofresearch.asia

info@journalofresearch.asia 


\title{
LEARNING STYLES AND METHODS OF TEACHING
}

\author{
Khodjaqulova Nargiza Khosiyatkulovna \\ A senior teacher at the English language department \\ Tashkent University of Information Technologies, Tashkent, \\ Uzbekistan
}

Abstract: In this article, four main learning styles have been analyzed. As it is known, there are different types of learners according to physical and psychological approach. The main ones are visual, auditory, tactile and kinaesthetic. Moreover, we made some research and gave some of them about different activities, which are proper for each learning style.

Key words: metacognitive, learning style, visual, auditory, tactile, kinaethetic, ESL, strategy, interact, preferences

\section{Introduction}

Many teachers who use learning styles and multiple intelligences in their classrooms wonder how important it is for students to know about these models. Experience has taught us that students who understand the models are better able to understand their own learning profiles, to develop flexibility and adaptability in their thinking, and to set realistic goals about minimizing learning weaknesses and maximizing strengths. In fact, research on the importance of metacognitive thinking supports the notion that instructional approaches that help students reflect on 
their own learning processes are highly beneficial to their overall learning and tend to stimulate motivation to improve as learners. ${ }^{47}$

Do you remember things better if you read them or if someone tells you? Do you like to repeat new vocabulary, study it while you are walking or make flashcards? Different people like to learn in different ways. These different ways are called learning styles. A learning style is the way a person learns best, understands best and remembers best. There are four basic learning styles:

$\checkmark \quad$ visual (seeing)

$\checkmark \quad$ kinaesthetic (moving, doing)

$\checkmark \quad$ auditory (hearing)

$\checkmark \quad$ tactile (touching or holding)

1. Visual learners like to learn new information by seeing it. Showing pictures or charts and writing important information on the blackboard will help visual learners practise and remember new ideas and information.

2. Auditory learners like to learn new information by hearing it. Short lectures, hearing the information in a song or asking students to repeat information aloud will help auditory learners remember new things.

3. Kinaesthetic learners prefer to learn new things by moving or doing. You can help your kinaesthetic students by asking them to act (talking with a friend in the bazaar). You can also ask them to write answers on the blackboard or ask them to work in a group with other students.

4. Tactile learners like to learn new information by touching or holding things. You can teach students who are tactile learners by giving

47 Brown, 1989; Marzano et al., 1988 
them objects (a blue paper, a red paper, a shoe and a sock), writing vocabulary words on a card for them to study, or giving them instructions written on a card. 48

\section{What learning style are your students?}

If you watch them you can guess what style is their best style. Kinaesthetic learners are always moving - tapping their foot or their hand, or moving back and forth. Auditory learners like to repeat things to themselves. Visual students like to see how things are spelled or read from a book instead of only listening. Tactile learners often like to write notes or hold different objects.

\section{What makes learning styles?}

Learning styles change according to age; very small children are very kinaesthetic. This is why they are always moving or doing something. At age, five or six they often become more tactile. At this age, they like to touch everything. Then, at age, eight or nine children usually become visual or auditory. Women are often auditory; men are often visual (but not always). We cannot change our students' learning styles, but we can change our teaching styles!

\section{Which style is best?}

All styles are the best! It is not possible to say that one style is better than another is. Traditional teaching is auditory and visual. This is not the best style, just the traditional style and it is not good for all of the students in a class.

What happens when a teacher only uses one type of activity?

48 Professional Development for Uzbekistan English Teachers Tashkent, 2009. № 1. P. 43-44 
If we only use auditory activities then we are only teaching the auditory learners in our class. The visual, kinaesthetic and tactile learners will have a difficult time understanding. They may get bored or frustrated and they might behave badly or cause problems. If we only use visual activities, then the auditory, tactile and kinaesthetic students will not understand or learn very well.

\section{How can a teacher teach students with different learning styles?}

When you plan your lesson check and be sure that the activities you planned are good for different learning styles. Some activities are good for two, three or four different styles. Instead of only talking, write information on the blackboard too (auditory and visual). Ask students to write their answers on the blackboard after they finish working (kinaesthetic and visual). Write instructions on a card and ask students to work in groups (tactile, kinaesthetic, auditory and visual).

We have different students: some are visual learners, some are auditory learners, and some are kinaesthetic or tactile learners. We need to remember to use different activities so that all our students can learn.

The students you interact with have different personalities, learning styles and preferences. A great ESL teaching strategy is one that integrates a variety of methods and techniques - appealing to this diversity of students - while allowing you to maintain relative flexibility to adapt to various classroom situations. ${ }^{49}$

Luckily, reaching out to different students is not guesswork for ESL teachers anymore. Differences in student preferences have been loosely categorized into 4 major learning styles.

${ }^{49}$ http://www.fluentu.com/english/educator/blog/esl-teaching-strategies-styles 
The categories are defined broadly, and it is not uncommon to find students that fit into more than one. Sure, a teacher may have an oddball who doesn't seem to fit into any group - but by appealing to these major learning styles and shaking up her classroom routine, she will be well on her way to reaching more students than ever before.

There have included a comprehensive description of the four learning styles below. Recommended classroom activities and teaching strategies are also included as a bonus to help the teacher to be a better, strategic ESL teacher!

\section{Visual (spatial)}

Pictures, images and spatial understanding are the preferred learning media of visual learners. These learners love to see lessons come to life, and often sit at the front of the class to not only get a full view of their teacher's body language and facial expressions, but also to avoid potential visual obstructions (and distractions).

\section{Tips for Teachers:}

Visual learners are a teacher has detailed note takers. They think in pictures and learn best from visual displays, slide shows, posters, clips and other visual tools. Sometimes, simple things like writing an outline of the grammar lesson on the board will also satisfy the visual learners' desire to take notes and capture everything in their own creative and vivid manners.

\section{Aural (auditory-musical)}

Auditory learners rely primarily on $\underline{\text { music }}$ and sound for their learning. Information is often best acquired through verbal lectures, discussions and mini-presentations. 


\section{Tips for Teachers:}

Auditory learners interpret the underlying meanings of words through listening to the tone, pitch, speed and other phonological nuances of your speech. Because written information may have little meaning to these students, auditory learners enjoy reading text aloud and may even bring a tape recorder to record the lecture. While the auditory learners are perfectly content with it, giving a 60-minute lecture, strategically integrating audio books, songs and movies into the lesson will stimulate their brain and wake up the non-auditory learners.

\section{Verbal (linguistic)}

These students learn best through words regardless of whether they are communicated in speech or writing. When learning something new, students who belong to this category prefer hearing a detailed explanation to viewing a physical, visual demonstration.

\section{Tips for Teachers:}

Like the auditory learners, verbal learners thrive in a traditional classroom lecture. However, they are also very interpersonal and welcome opportunities to interact with words and sounds through discussions, asking questions and teaching others. In general, verbal learners make great teacher's helpers and thrive in-group activities that involve lots of interactions and words.

\section{Auditory Learners}

Students with this style will be able to recall what they hear and will prefer oral instructions. They learn by listening and speaking. These students enjoy talking and interviewing. They are phonetic readers who 
Asian Journal of Research

№ 2 (2), March 2017 www.journalofresearch.asia

info@journalofresearch.asia

enjoy oral reading, choral reading, and listening to recorded books. They learn best by doing the the following:

$\checkmark$ interviewing, debating

$\checkmark$ participating on a panel

$\checkmark$ giving oral reports

$\checkmark$ participating in oral discussions of written material

\section{Visual Learners}

Visual learners will be able to recall what they see and will prefer written instructions. These students are sight-readers who enjoy reading silently. Better yet, present information to them with a video. They will learn by observing and enjoy working with the following:

$\checkmark$ computer graphics

$\checkmark$ maps, graphs, charts

$\checkmark$ cartoons

$\checkmark$ posters

$\checkmark$ diagrams

$\checkmark$ graphic organizers

$\checkmark$ text with a lot of pictures

\section{Tactile Learners}

Students with this strength learn best by touching. They understand directions that they write and will learn best through manipulatives. The teacher should try using the Language Experience Approach (LEA) when teaching these students to read. These students will also benefit from whole language approaches to reading. They'll learn best by :

$\checkmark$ drawing

$\checkmark$ playing board games 
$\checkmark$ making dioramas

$\checkmark$ making models

$\checkmark$ following instructions to make something

\section{Kinesthetic Learners}

Kinesthetic learners also learn by touching or manipulating objects. They need to involve their whole body in learning. Total Physical Response is a good ESL method for them. They remember material best if they act it out. These students learn best by:

$\checkmark$ playing games that involve their whole body

$\checkmark$ movement activities

$\checkmark$ making models

$\checkmark$ following instructions to make something

$\checkmark$ setting up experiments

\section{Conclusion}

As we have mentioned in this article, students are humans, too. They differ from each other in their preferences. When it comes to learning a new language, each student receives, processes and stores information differently. Some students may thrive using traditional papers and pencils, while others prefer collaboration and even hands-on activities. If their ideal learning styles are not recognized in the classroom, studying becomes drudgery - and students who have a hard time tend to lose their motivation. In conclusion, we can say that it depends on a teacher how to conduct her lesson. If she is creative teacher she will take into account learning styles of her students. In one lesson 
Asian Journal of Research

№ 2 (2), March 2017 www.journalofresearch.asia info@journalofresearch.asia

she should be all learning styles in order to get involved all students and to teach them in a proper way.

\section{References}

1. Professional Development for Uzbekistan English Teachers Tashkent, 2009. № 1. C. 43-44

2. Brown, 1989; Marzano et al., 1988

3. http://www.fluentu.com/english/educator/blog/esl-teachingstrategies-styles/

4. http://www.everythingesl.net/inservices/learningstyle.php 
Asian Journal of Research

№ 2 (2), March 2017 www.journalofresearch.asia

info@journalofresearch.asia

Author information:

\section{Khodjaqulova Nargiza Khosiyatqulovna}

Academic title PhD, MA etc. A senior teacher of English language

Name of University, Institution Company name, Country Tashkent University of Information Technologies

E-mail: nargiza.khodjaqulova@mail.ru

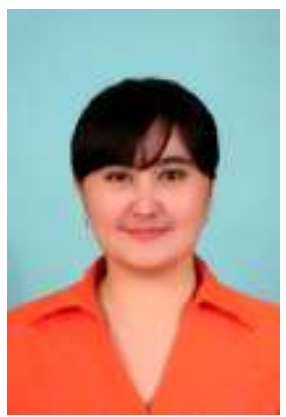

